\title{
DECOUPLING ASIA REVISITED
}

Cyn-Young Park

NO. 506

January 2017
ADB ECONOMICS WORKING PAPER SERIES 
ADB Economics Working Paper Series

\section{Decoupling Asia Revisited}

Cyn-Young Park

No.506 | January 2017
Cyn-Young Park (cypark@adb.org) is director of the Regional Cooperation and Integration Division in the Economic Research and Regional Cooperation Department of the Asian Development Bank.

The author wishes to thank Abigail Golena, Paul Mariano, Ana Kristel Molina, and Mara Claire Tayag for their excellent research support. 
(c) 2017 Asian Development Bank

6 ADB Avenue, Mandaluyong City, 1550 Metro Manila, Philippines

Tel +632 632 4444; Fax +6326362444

www.adb.org

Some rights reserved. Published in 2017.

Printed in the Philippines.

ISSN 2313-6537 (Print), 2313-6545 (e-ISSN)

Publication Stock No. WPS178597-2

DOI: http://dx.doi.org/10.22617/WPS178597-2

Cataloging-In-Publication Data

Asian Development Bank.

Decoupling Asia revisited.

Mandaluyong City, Philippines: Asian Development Bank, 2017.

1. Business cycle. 2. Emerging Asia. 3. Financial integration. 4. Trade integration. I. Asian Development Bank.

The views expressed in this publication are those of the authors and do not necessarily reflect the views and policies of the Asian Development Bank (ADB) or its Board of Governors or the governments they represent.

ADB does not guarantee the accuracy of the data included in this publication and accepts no responsibility for any consequence of their use. The mention of specific companies or products of manufacturers does not imply that they are endorsed or recommended by ADB in preference to others of a similar nature that are not mentioned.

By making any designation of or reference to a particular territory or geographic area, or by using the term "country" in this document, $A D B$ does not intend to make any judgments as to the legal or other status of any territory or area.

This work is available under the Creative Commons Attribution 3.0 IGO license (CC BY 3.0 IGO)

https://creativecommons.org/licenses/by/3.0/igo/. By using the content of this publication, you agree to be bound by the terms of this license.

This CC license does not apply to non-ADB copyright materials in this publication. If the material is attributed to another source, please contact the copyright owner or publisher of that source for permission to reproduce it. $A D B$ cannot be held liable for any claims that arise as a result of your use of the material.

Attribution-You should always acknowledge ADB as the source using the following format:

[Author]. [Year of publication]. [Title of the work in italics]. [City of publication]: [Publisher]. (c) ADB. [URL or DOI] [license].

Translations-Any translations you create should carry the following disclaimer:

Originally published by ADB in English under the title [title in italics]. (c) ADB. [URL or DOI] [license]. The quality of the translation and its coherence with the original text is the sole responsibility of the translator. The English original of this work is the only official version.

Adaptations-Any adaptations you create should carry the following disclaimer:

This is an adaptation of an original work titled [title in italics]. (c) ADB. [URL or DOI][license]. The views expressed here are those of the authors and do not necessarily reflect the views and policies of ADB or its Board of Governors or the governments they represent. ADB does not endorse this work or guarantee the accuracy of the data included in this publication and accepts no responsibility for any consequence of their use.

Please contact pubsmarketing@adb.org if you have questions or comments with respect to content, or if you wish to obtain copyright permission for your intended use that does not fall within these terms, or for permission to use the ADB logo.

Notes:

1. In this publication, " $\$$ " refers to US dollars.

2. Corrigenda to ADB publications may be found at http://www.adb.org/publications/corrigenda 


\section{CONTENTS}

TABLES AND FIGURES

ABSTRACT vi

$\begin{array}{ll}\text { I. INTRODUCTION } & 1\end{array}$

II. LITERATURE REVIEW: ECONOMIC INTEGRATION AND BUSINESS CYCLE
SYNCHRONIZATION

III. BUSINESS CYCLE SYNCHRONIZATION IN ASIA

A. Asia's Business Cycle Correlations within and beyond the Region 4

B. Intra-Asian Trade: The People's Republic of China's Role and Vertical

Supply Networks $\quad 6$

C. The Trade-Foreign Direct Investment Nexus: Global Production Sharing in Asia 12

IV. FINANCIAL INTEGRATION AND SPILLOVERS 14

A. Empirical Analysis of Asia's International Assets Portfolio 14

B. Macroeconomic Interdependence: Vector Autoregression Model and Results 19

V. CONCLUSION 22

$\begin{array}{ll}\text { APPENDIX } & 25\end{array}$

$\begin{array}{lr}\text { REFERENCES } & 29\end{array}$ 
TABLES AND FIGURES

\section{TABLES}

$1 \quad$ Most Common Economy Pairs for Trade-Oriented FDI Firms 12

2 Inward FDI from Trade-Oriented FDI Firms-EEA Economies, by Sector 13

3 Number of FDI Firms by Parent Economy 13

$4 \quad$ Simple Correlations in Financial Asset Returns 17

\section{FIGURES}

1 Business Cycle Correlations-EEA 5

2 Median Instantaneous Quasi-Correlations of Real GDP Growth Rates-EEA 6

3 Instantaneous Quasi-Correlations of Real GDP Growth Rates-EEA 7

4 Destination of EEA Exports 8

$5 \quad$ Correlation between Growth in EEA Exports and US Non-oil Imports 9

6 Value-Added Export Decomposition-Emerging East Asia, 2011

$7 \quad$ People's Republic of China Export and Import Share, by Partner 11

8 People's Republic of China Export and Import Share, by Commodity Groups 11

9 Cross-border Portfolio Asset Holdings by AXC 15

10 Cross-border Portfolio Liabilities by EEA

11 Cross-border Portfolio Asset Holdings-AXC plus Japan 16

12 Dynamic Conditional Correlations of Equity Market Returns-EEA 18

13 Dynamic Conditional Correlations of Bond Market Returns-EEA 19

14 Impulse Responses of AXC Business Cycles to External Shocks 21

15 Share of AXC Output Variances Due to External and Local Factors 22

Appendix Figure: Share of Output Variances Due to External and Local Factors 25 


\begin{abstract}
The issue of decoupling is controversial. On the back of Asia's sustained high growth, the hypothesis that the region's business cycles would become increasingly independent of the global trend gained considerable attention. Asia was nonetheless hit hard by the global financial crisis and subsequent economic downturn. This paper focuses on the evolution and nature of macroeconomic interdependence between emerging East Asia and Group of 3 economies. First, the progress of regional economic integration has positively impacted the direction and magnitude of macroeconomic interdependence and growth spillovers both intraregionally and interregionally. Second, with the People's Republic of China (PRC) playing a central role in the regional production and trade network, its ongoing structural changes will likely influence Asia's economic integration both within and beyond the region through evolving trade and investment links. Finally, the paper employs a vector autoregression model to assess the impact of the United States (US) output, world trade, financial volatility, and the PRC output shocks on emerging East Asia. Findings suggest that the US economy remains an important source of external demand shock for the regional economy, although the impact of the PRC has increased sharply.
\end{abstract}

Keywords: business cycle, emerging Asia, financial integration, trade integration

JEL codes: F15, F36, F44 


\section{INTRODUCTION}

Asia's integration and rise as a main driver of global production and trade is reshaping the global economic landscape. East and Southeast Asia (grouped together as emerging East Asia [EEA]) now account for about $25 \%$ of total global trade and $21 \%$ of global gross domestic product (GDP), compared to about $10 \%$ and $5.8 \%$ in 1985 . $^{.}$The region has made remarkable economic progress, with an annual growth rate averaging at 7.6\% between 1985 and 2015. This performance has been underpinned by dynamic growth in the People's Republic of China (PRC), which contributed around 4.5 percentage points to this growth during the 30-year period.

The PRC has emerged as a major player in the world economy as a producer and exporter of manufacturing goods and a consumer of primary commodities. The PRC plays a central role in the Asian production network, with the tightening of intraregional trade and investment links fundamentally changing the nature of macroeconomic interdependence and growth spillovers between the region and major advanced economies.

The issue of "decoupling" is controversial. The decoupling of Asia, the divergence of the region's business cycles from those of other regions, can be based on arguments about the emergence of regional economic dynamics that are independent of economic fluctuations in other parts of the world, especially major industrial countries.

In a narrow setting, decoupling is a question of whether EEA will be able to maintain high growth rates regardless of economic swings in major advanced economies, the US in particular. But in a broader sense, it is about the evolving nature of macroeconomic interdependence between EEA and the traditional economic powers, given the region's growing economic prowess and influence in the global economy.

From the early 2000s until the global financial crisis (GFC) of 2008, EEA maintained strong growth, seemingly unaffected by the ups and downs of major advanced economies. On the back of the region's sustained high growth, the decoupling hypothesis gained considerable attention from market participants and commentators. ${ }^{2}$ Asia was nonetheless hit hard by the GFC and economic downturn in its aftermath. A sharp increase in the business cycle comovement between Asia and major advanced economies after the crisis seemed to discredit the "decoupling" hypothesis and rather reconfirm that Asia remains highly dependent on the global economy.

Given the weaker than expected economic recovery in the United States (US) and subdued growth prospects in Europe, it is high time to revisit the region's potential to lead the global economic recovery as an independent source of growth. The ongoing reforms and economic restructuring in the PRC also present the potential changes in its role in factory Asia through regional trade and investment linkages. With strong policy efforts to rebalance, EEA's economic performance has been solid despite the visible slowing in the European Union (EU), Japan, and the US economies in the aftermath of the GFC. This prompts the following review of the debate on Asia's decoupling from the global economy.

1 Throughout this study, Asia refers to nine selected economies East and Southeast Asia. The nine Asian economies that are selected for the study include the People's Republic of China; Hong Kong, China; Indonesia; the Republic of Korea; Malaysia; the Philippines; Singapore; Taipei,China; and Thailand.

2 The Economist on May 6, 2008: "The decoupling debate”; and Bloomberg Businessweek on March 20, 2008: "Are Asian Economies Decoupling from U.S.?” 
This paper focuses on the evolution and nature of macroeconomic interdependence between EEA and the Group of 3 (G3) economies - the US, Japan, and the EU. First, the progress of regional economic integration has likely impacted the direction and magnitude of macroeconomic interdependence and growth spillovers both intraregionally and between regions. While greater regional economic integration may lead to greater output comovements within the region, it may not necessarily reduce the business cycle synchronization between the region and the rest of the world, especially with major advanced economies.

Second, the PRC plays a special role in the closely knit regional trade and investment relationship. Intra-Asian trade has been driven in part by strong expansion of regional supply networks established by multinational companies. The PRC has become a regional hub of manufactured production by hosting the production process of many multinationals and attracting most inward foreign direct investment (FDI) to the region. Given the PRC's increasing influence in regional and global economies, the impact of the PRC economy on the global and regional business cycle is of particular interest.

Finally, evidence presented in this study suggests that the US economy remains an important source of external demand shocks for the regional economy, although the impact of the PRC has increased sharply in parallel. The paper will employ a vector autoregression (VAR) model to assess the impact of the US output, world trade, financial volatility, and the PRC output shocks on EEA.

This paper is organized as follows. Section II presents a concise literature survey on the issues of economic integration and business cycle synchronization focusing on both intraregional and interregional integration for EEA. Section III examines the evolution of business cycle synchronization through changing trade and financial linkages both within and beyond the Asian region. It will investigate the role of the PRC in shaping these changes. Section IV evaluates the impact of growth spillovers and macroeconomic interdependence between EEA and the G3 economies. Section $V$ concludes.

\section{LITERATURE REVIEW: ECONOMIC INTEGRATION AND BUSINESS CYCLE SYNCHRONIZATION}

The effect of economic integration on business cycle comovement in theory is ambiguous. A substantial literature has investigated the impact of trade linkages on business cycle synchronization. Frankel and Rose (1998) empirically showed that increased trade integration leads to greater convergence in business cycles by allowing aggregate demand shocks to spread more easily across borders. Such spillover effects can be also made through changes in the relative prices of factors and products. For example, a change in the relative price of labor-intensive goods due to a positive shock in an economy can spill over to higher wages and employment in other countries through free trade (Kraay and Ventura 2007). Following the seminal paper by Frankel and Rose (1998), many empirical studies have confirmed that trade intensity increases business cycle synchronization, albeit at varying degrees depending on country-specific economic structures (e.g., Baxter and Kouparitsas 2005; Imbs 2004; Inklaar, Jong-A-Pin, and de Haan 2008).

However, free trade may not necessarily lead to convergence in cross-country business cycles, if stronger trade linkages induce the specialization of production. Kose and Yi (2002) argued that increased trade linkages would likely encourage countries to specialize in certain production, and that increased interindustry specialization across countries would decrease the comovement of international business cycles. In this context, not just the size of trade but also similarities in industrial structures would be important for explaining output cofluctuations. 
A few related studies focus specifically on the similarity of production structures as an important determinant of output comovements. They show the effect of industrial structure in crossborder spillovers through the trade channel. Industry-specific shocks can cause more business cycle synchronization among countries with similar production structures. Clark and van Wincoop (2001), Imbs (2004), and Shin and Wang (2004) provide evidence that greater similarity in industry structure is associated with more synchronicity in output and employment. Imbs emphasizes that when bilateral trade is driven more by intra-industry trade than by interindustry trade, output comovement tends to strengthen.

The effect of financial integration on output comovement is even more controversial. Financial integration can help increase efficiency of financial resource allocation across countries; for example, by moving capital from a country with a negative shock to that with a positive shock, implying a negative output correlation. Kalemli-Ozcan, Sørensen, and Yosha (2003) demonstrate that better risk sharing through greater financial integration can lead to higher specialization of production and hence less symmetric output fluctuations. Heathcote and Perri (2004) also present evidence that higher financial integration can lead to a decline in the correlation of output in a two-country, two-good model.

However, Imbs (2006) empirically shows that a higher degree of financial integration leads to greater business cycle synchronization between two economies. Empirical literature on financial crises and financial contagion also tends to highlight direct and positive effects of financial integration on business cycle synchronization (Calvo and Reinhart 1996; Claessens, Dornbusch, and Park 2001; Kose, Prasad, and Terrones 2003, 2007). Especially in the crisis context, with imperfect information or liquidity constraints, flight to safety can cause investors to withdraw capital from many countries simultaneously, contributing to positive output correlation. Kim, Kim, and Wang (2007) illustrate how shocks to capital flows generate positive business cycle correlation for countries in Asia and the Pacific. Kim and Kim (2013) also examine the role of capital market liberalization in business cycle synchronization among Asian economies by providing empirical evidence for the positive effect of international capital flows in output comovement.

The effect of trade and financial linkages on business cycle comovement also hinges on more broad socioeconomic and policy factors, such as cross-country differences in industrial structure, factor intensity, macroeconomic policies, and foreign exchange regimes. With increasingly globalized trade and financial settings, policy making (notably monetary policy) shows a tendency of crosscountry convergence. In general, greater integration may call for greater macroeconomic policy cooperation across borders in order to manage spillovers and macroeconomic interdependence more effectively.

The nature and extent of business cycle comovement is ultimately an empirical question. Several studies adopt dynamic factor models, which can decompose an economy's output fluctuations into contributions by different factors such as global, regional, and country-specific factors. Moneta and Rüffer (2006) find that there is a significant common factor in outputs of 10 East Asian economies, not including the PRC and Japan, using various specifications of a dynamic factor model. Their findings show the common factor is mainly the result of comovement in exports, as well as some exogenous factors such as oil price and the Japanese yen to US dollar exchange rate. But, crosscountry spillover effects do not explain a large share of the comovement in Asia. 
Other empirical studies also suggest that the business cycles of Asian economies have increasingly synchronized, partly due to deepened trade integration. Shin and Wang (2004) employ a panel regression to show that intra-industry trade is the major channel for business cycle convergence between the Republic of Korea and other Asian economies. Abeysinghe and Forbes (2005) develop a structural VAR model to examine how a shock to a country would transmit to 11 Asian economies, as well as the US and the rest of the Organisation for Economic Co-operation and Development. They estimate the multiplier effects of a shock using trading linkages, which are large and significant, while different from the predicted patterns using bilateral trade matrix. Kim and Lee (2008) examine the extent of output interdependence among Asian economies, and for Asia and the world, using a VAR approach to find that regional influence increased as much as global influence in Asian outputs after the Asian financial crisis (AFC) of 1997/98.

Empirical studies seem to suggest varying degrees of macroeconomic interdependence in Asia, depending on the choice of empirical methodology and measures of integration. Although recent studies have found evidence for increasing output interdependence among Asian economies, especially after the AFC, the results remain inconclusive as to whether the outputs of Asian economies have become more independent and "decoupled" from those of the industrialized economies. Helbling et al (2007) and Kose, Otrok, and Prasad (2008) find that the global and regional common shocks have accounted for a sizable fraction of business cycle fluctuations in both industrial countries and emerging market economies, but the relative importance of the global factors has decreased, while that of regional factors increased. The result supports for "decoupling" or "divergence" of business cycles between industrialized countries and Asian economies. However, Kim, Lee, and Park (2009) provide empirical evidence to support "recoupling" of Asian economies with major advanced countries, rather than "decoupling," with findings indicating that economic interdependence between Asian and major advanced economies increased significantly after the AFC.

\section{BUSINESS CYCLE SYNCHRONIZATION IN ASIA}

This section looks into the evolution of business cycle comovements among EEA, the PRC, and major industrialized economies.

\section{A. Asia's Business Cycle Correlations within and beyond the Region}

Figure 1 illustrates the correlations of quarterly real business cycles in EEA with Japan, the EU, and the US as well as among subregional groupings within EEA using 12-quarter (3-year) moving averages. For example, the correlation in Q4 2015 is calculated as the average correlation between EEA and the US over a 12-quarter period ending in Q4 2015

Figure 1 also presents the average of the bilateral correlations within EEA and between EEA and $\mathrm{G} 3$ economies in the sample over three periods: (i) pre-AFC (Q1 1985-Q1 1997), (ii) pre-GFC (Q1 1999-Q3 2007), and (iii) post-GFC (Q3 2009-Q2 2016) to separate the high crisis impact on the business cycle comovements. Pre-GFC and post-GFC can be also grouped as post-AFC. The correlation analysis shows that business cycle correlations between EEA and G3 increased visibly in the post-AFC period, but generally declined post-GFC.

EEA's intraregional business cycle correlations also increased in the post-AFC period, although decreased slightly post-GFC. The results also show that the comovement between the PRC and the 
rest of EEA business cycles increased in the post-AFC period, although the correlation weakened in the post-GFC period.

\section{Figure 1: Business Cycle Correlations-EEA}

(a) With $\mathrm{G}_{3}$ economies

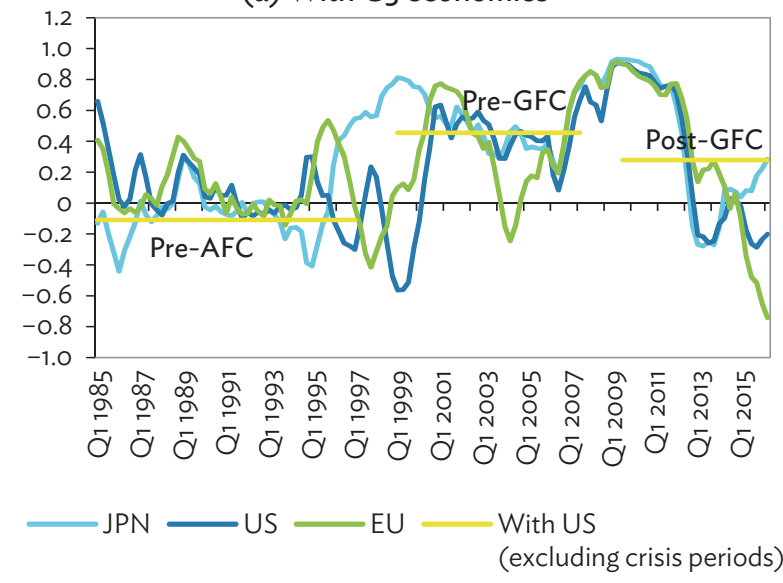

(b) Intrasubregional correlation

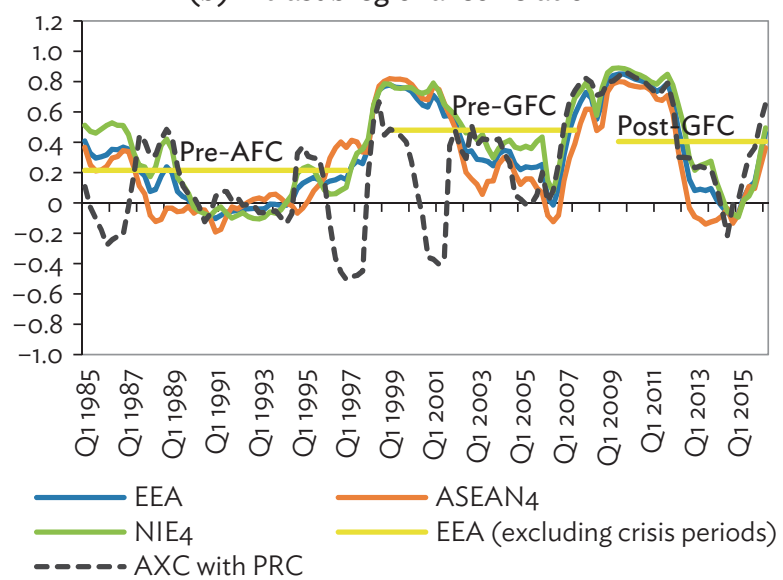

$\mathrm{AFC}=$ Asian financial crisis, $\mathrm{ASEAN}=$ Association of Southeast Asian Nations, $\mathrm{AXC}=\mathrm{EEA}$ excluding the PRC, EEA = emerging East Asia, $\mathrm{EU}=$ European Union, GDP = gross domestic product, GFC = global financial crisis, JPN = Japan, NIE = newly industrialized economy, PRC $=$ People's Republic of China, US = United States.

Notes: G3 includes euro area, Japan, and the US. EEA includes ASEAN4 (Indonesia, Malaysia, Philippines, and Thailand); NIE4 (Hong Kong, China; Republic of Korea; Singapore; and Taipei,China); and the PRC. Three-year moving correlations based on cyclical HodrickPrescott filtered seasonally adjusted GDP at constant prices.

Source: ADB calculations using data from Oxford Economics. Global Economic Databank. http://www.oxfordeconomics.com/ (accessed October 2016).

Instead of average 3-year moving bilateral correlations, we also adopt the instantaneous quasicorrelation measures, which was first proposed by Abiad et al. (2013) and used in Duval et al. (2014), to remove the lagged effects of the financial crises in moving averages when correlations are calculated over rolling windows of 3 years. ${ }^{3}$ Using annual data on real GDP growth rates, quasi-correlations of EEA with itself and with Japan, the EU, and the US since 1985 are depicted in Figures 2 and 3.

3 The instantaneous quasi-correlation measure of business cycle synchronization is computed as:

$$
\operatorname{QCORR}_{i j t}=\frac{\left(g_{i t}-g_{i}^{*}\right) *\left(g_{j t}-g_{j}^{*}\right)}{\sigma_{i}^{g} * \sigma_{j}^{g}}
$$

where $Q C O R R_{i j t}$ is the quasi-correlation of real GDP growth rates of country $i$ and $j$ in year $t, g_{i t}$ denotes the output growth rate of country $i$ and $j$ in year $t$ and; $g_{i}^{*}$ and $g_{j}^{*}$ represent the mean and standard deviation of output growth rate of country $i$, respectively, during the sample period. The growth rate is the first difference of the log of real GDP (See Abiad et al. 2013; Duval et al. 2014). 
Figure 2: Median Instantaneous Quasi-correlations of Real GDP Growth Rates-EEA

(a) EEA with $\mathrm{G}_{3}$

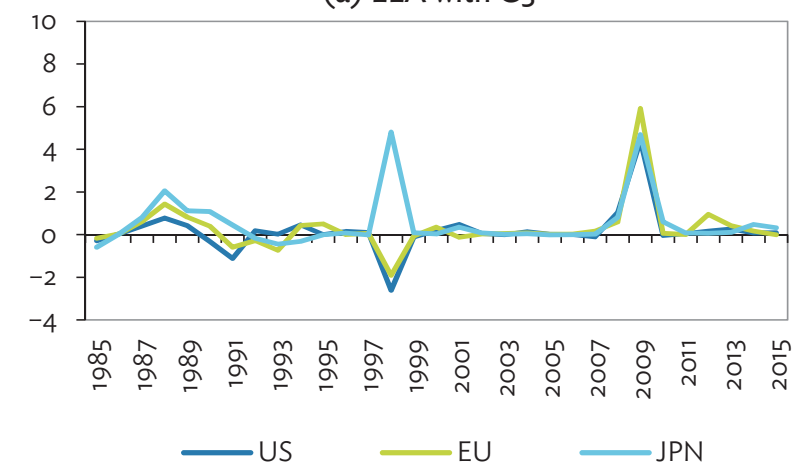

(b) Intrasubregional correlations

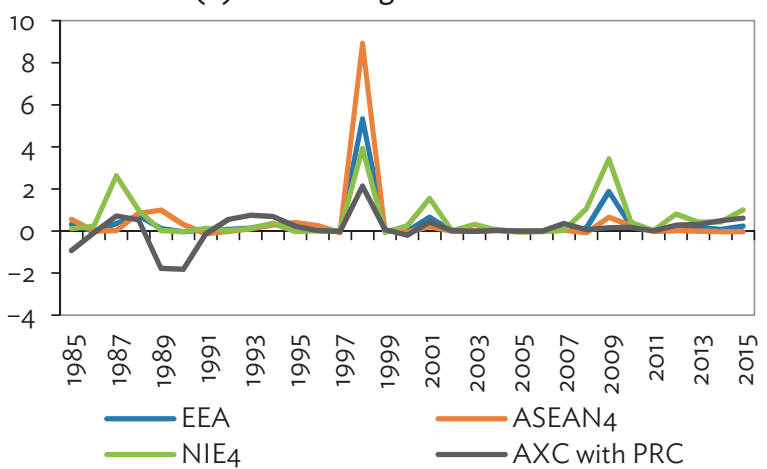

ASEAN = Association of Southeast Asian Nations, AXC = EEA excluding the PRC, EEA = emerging East Asia, EU = European Union, GDP = gross domestic product, JPN = Japan, NIE = newly industrialized economy, PRC = People's Republic of China, US = United States. Notes: G3 includes euro area, Japan, and the US. AXC includes ASEAN4 (Indonesia, Malaysia, Philippines, and Thailand) and NIE4 (Hong Kong, China; Republic of Korea; Singapore; and Taipei,China). Based on the methodology of Abiad, Abdul, Davide Furceri, Sebnem Kalemli-Ozcan, and Andrea Pescatori. 2013. "Dancing Together? Spillovers, Common Shocks, and the Role of Financial and Trade Linkages." In World Economic Outlook, October, 81-111. Washington: International Monetary Fund.

Source: ADB calculations using data from Oxford Economics. Global Economic Databank. http://www.oxfordeconomics.com/ (accessed October 2016).

Consistent with findings from similar studies, business cycle correlations sharply increased during crisis times (Figure 2). The largest spikes occurred around the AFC for the region's economiesintraregionally for EEA and between EEA excluding the PRC (AXC) and the PRC. The region's business cycle correlations with the EU and the US were largest during the GFC. During normal times (or excluding the crisis period), the instantaneous quasi-correlations were much smaller in general. But Figure 3 shows an increase in instantaneous quasi-correlations between EEA and Asia's large economies (both the PRC and Japan) after the GFC, more with the PRC than with Japan. The instantaneous quasi-correlation with the US increased after the AFC but declined after the GFC. Among subregional groupings of EEA, both intraregional and interregional business cycle correlations are particularly high for the high-income NIE4 economies of Hong Kong, China; the Republic of Korea; Singapore; and Taipei,China.

Although registering somewhat slower growth than in the fast expansion phase in the 1990s before the AFC, most Asian economies resumed relatively strong growth prior to the GFC of 2008. Business cycle synchronicity seems to have also increased since the AFC both intraregionally and between the region and the $\mathrm{G} 3$ economies, although it has weakened a little after 2008.

\section{B. Intra-Asian Trade: The People's Republic of China's Role and Vertical Supply Networks}

Trade is often considered as an important channel through which economic shocks are transmitted from one country to another. Export-driven growth may expose countries' vulnerabilities to economic conditions of their trading partners and external market environments.

EEA has achieved rapid economic expansion underpinned by strong export performance over the past few decades. The export-to-GDP ratio rose rapidly from 25\% in 1985 to a peak of $46 \%$ in 2006 , before declining steadily to reach $29 \%$ in 2015 . The region's average ratio over the period 1985- 
2015 was 35\%, much higher than the world average of 19\%, attesting to the export-oriented growth strategy in the region.

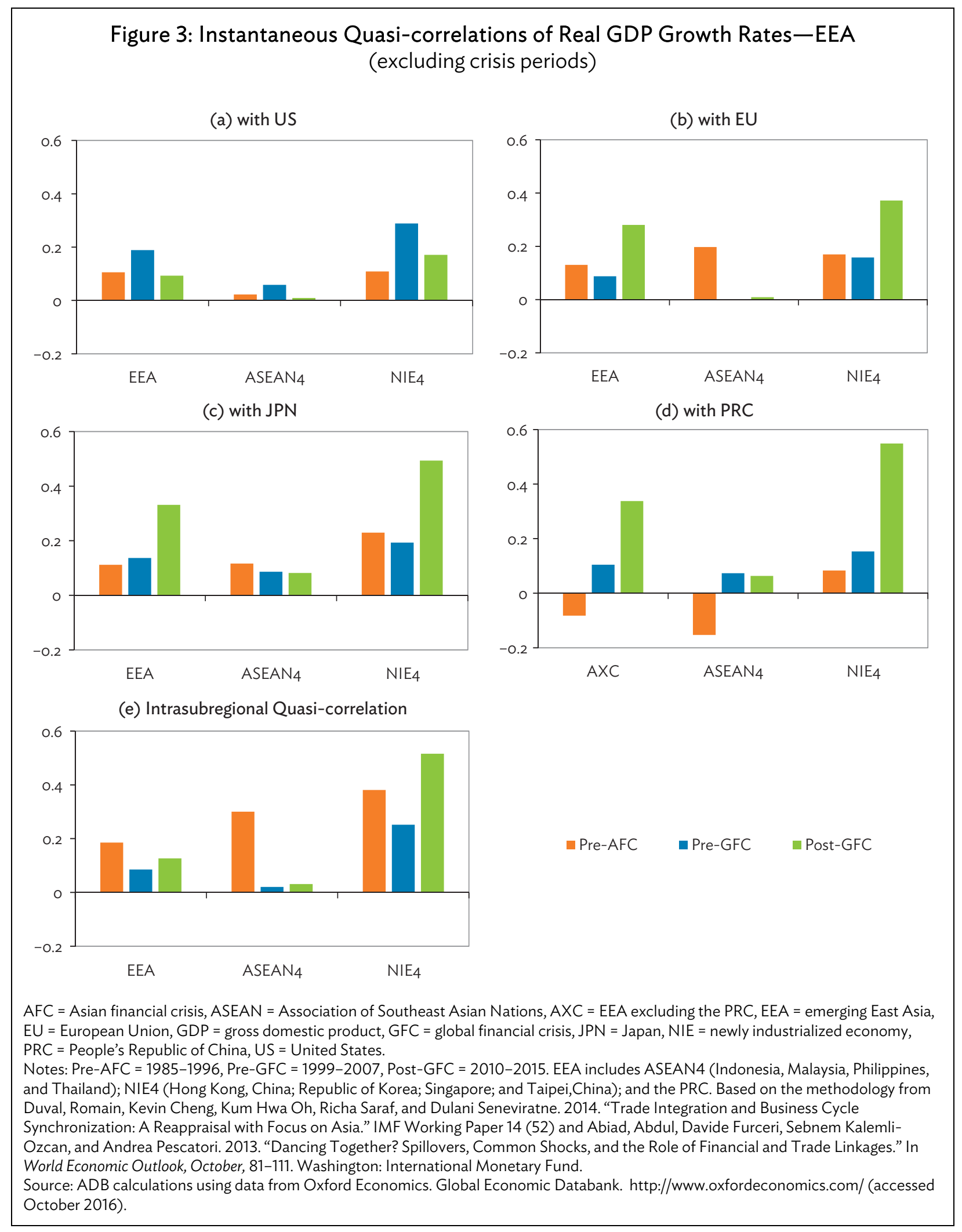


However, the region's high reliance on exports has been accompanied by significant progress in diversification of its export base. Figure 4 shows the composition of EEA's exports by destination. The geographical composition of Asia's export market has become much more diversified, with the share of the single largest market, namely the US, at only $14 \%$ in 2015, down from 23\% in 1990 . The G3 economies (the EU, Japan, and the US) collectively account for $29 \%$ of EEA's total exports, down from almost 50\%. On the other hand, EEA's exports to other developing economies (Africa, Latin America, and the Middle East) merely rose from $5 \%$ to $12 \%$.

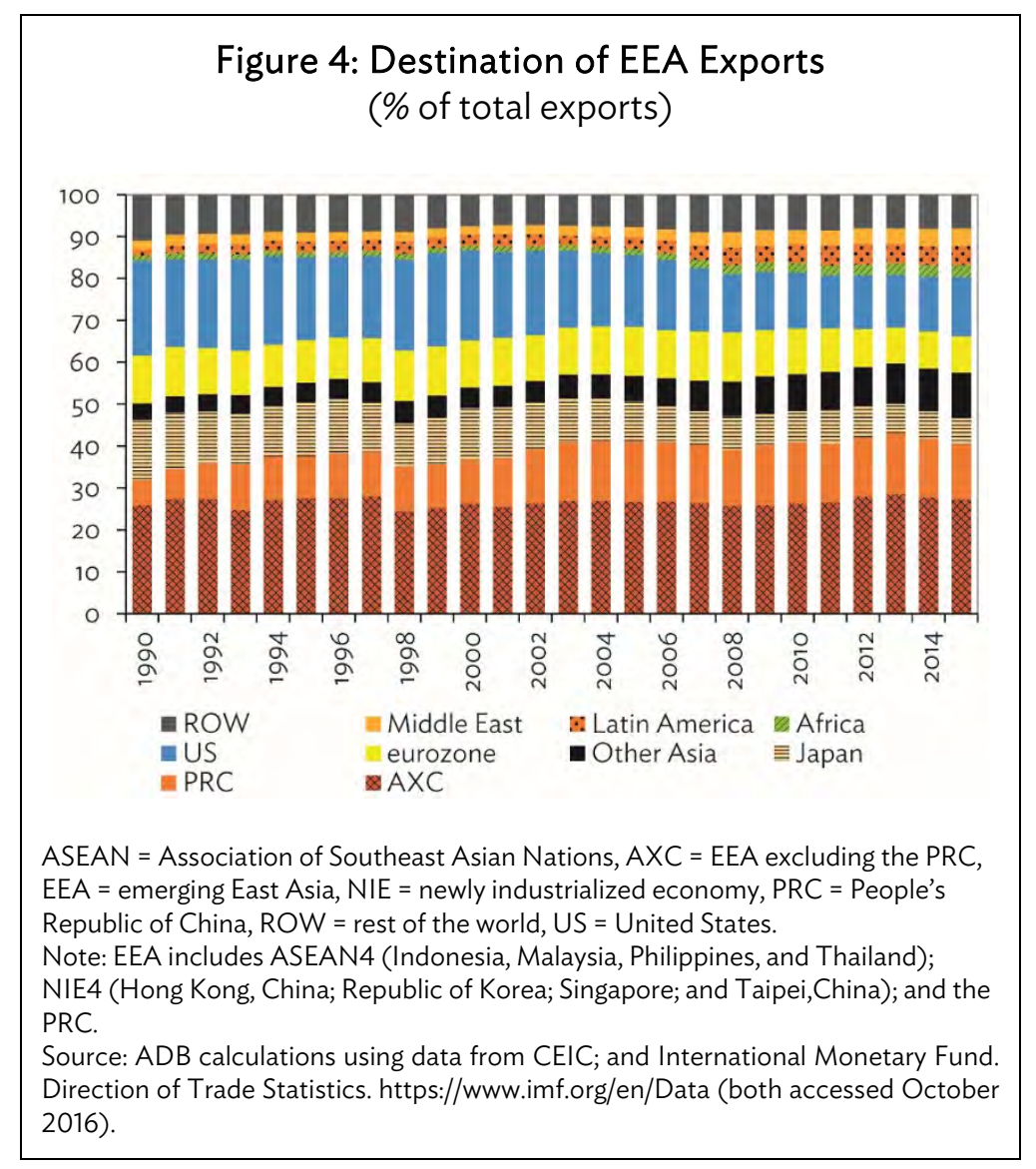

Greater diversification in the destination of Asian exports suggests that an idiosyncratic demand shock from a single market may be mitigated to some extent by stronger growth in other export markets. At the same time, the share of intraregional trade of EEA economies in total exports rose from 32\% in 1990 to around 41\% in 2015. The PRC now accounts for around 30\% of EEA's intraregional exports, from $20 \%$ in 1990. Strong growth in intraregional trade including the PRC has been also viewed as evidence for EEA's greater resilience to cyclical fluctuations in the major trading partners outside the region.

However, changing demand conditions in the world's major economies-particularly the USappear to represent still a dominant factor behind EEA's export growth. Figure 5 demonstrates a tight relationship between US non-oil import growth and Asian export growth. The US non-oil imports account for about $60 \%$ of total $\mathrm{G} 3$ non-oil imports, while highly synchronized with movements of $\mathrm{G} 3$ non-oil imports. Consequently, the correlation between EEA exports and G3 non-oil import growth should be also quite significant. Although the share of G3 markets in Asia's total export market is on a decline, the figure indicates that the relationship has strengthened: The decadal correlations between 
growth rates of US non-oil imports and Asian exports confirm that this linkage is significant and tighter in the 2000s.

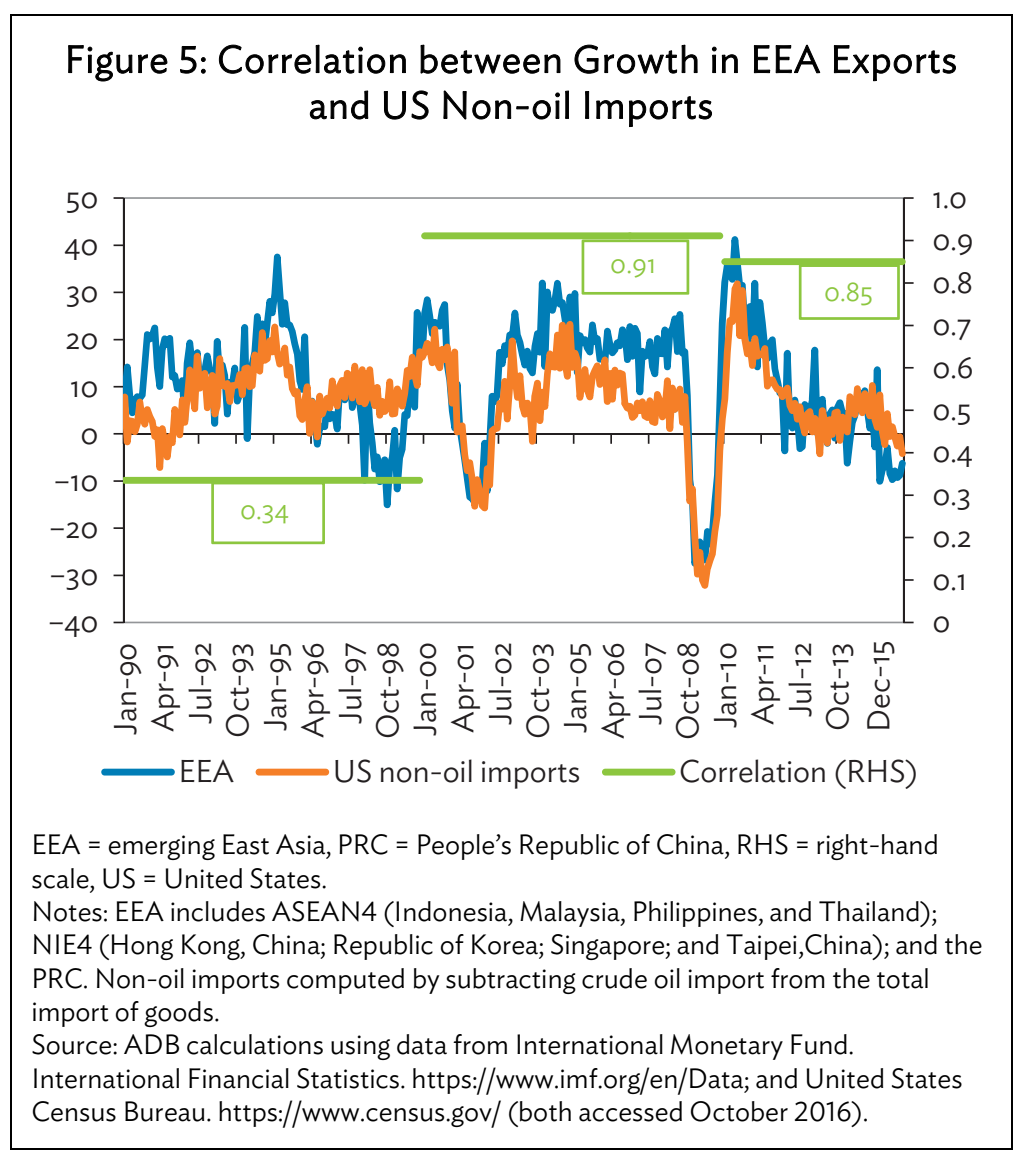

Underlying this strong linkage is the nature of intra-Asian trade. A marked feature of intraAsian trade is that it is driven by vertical integration of production chains, whose final output is destined for markets outside the region. Figure 6 shows a breakdown of EEA exports to those destined for other countries within the region and those elsewhere, based on the global value chain database. The database was availed from ADB Multiregion Input-Output tables using the methodology from Wang, Wei, and Zhu (2014). ${ }^{4}$ Intraregional trade within EEA is then factored into the region's final demand and what is used in the production process. A similar decomposition is made for the trade among the rest of the world. Both ends report total final demand by different regions, which take into account the trade of intermediate goods in the production process for final demands. Based on our estimates, about $41.9 \%$ of total EEA exports (instead of about $29 \%$ of total exports shown above) are eventually consumed by $\mathrm{G} 3$ countries. The results show that the $\mathrm{G} 3$ countries remain as main export destinations for final goods that leave EEA, when taking into account the share of intermediate goods trade that is for assembly and production within the region but eventually shipped out.

4 Except for Bangladesh, Malaysia, the Philippines, Thailand, and Viet Nam Input-Output tables, which were constructed by $A D B$, the rest were sourced from the World Input-Output Database. While the World Input-Output Database and ADB Multiregion Input-Output tables have been constructed in a clear conceptual framework on the basis of officially published input-output tables in conjunction with national accounts and international trade statistics, level numbers are likely to remain different from those officially released by the respective economies. 
Figure 6: Value-Added Export Decomposition-Emerging East Asia, 2011

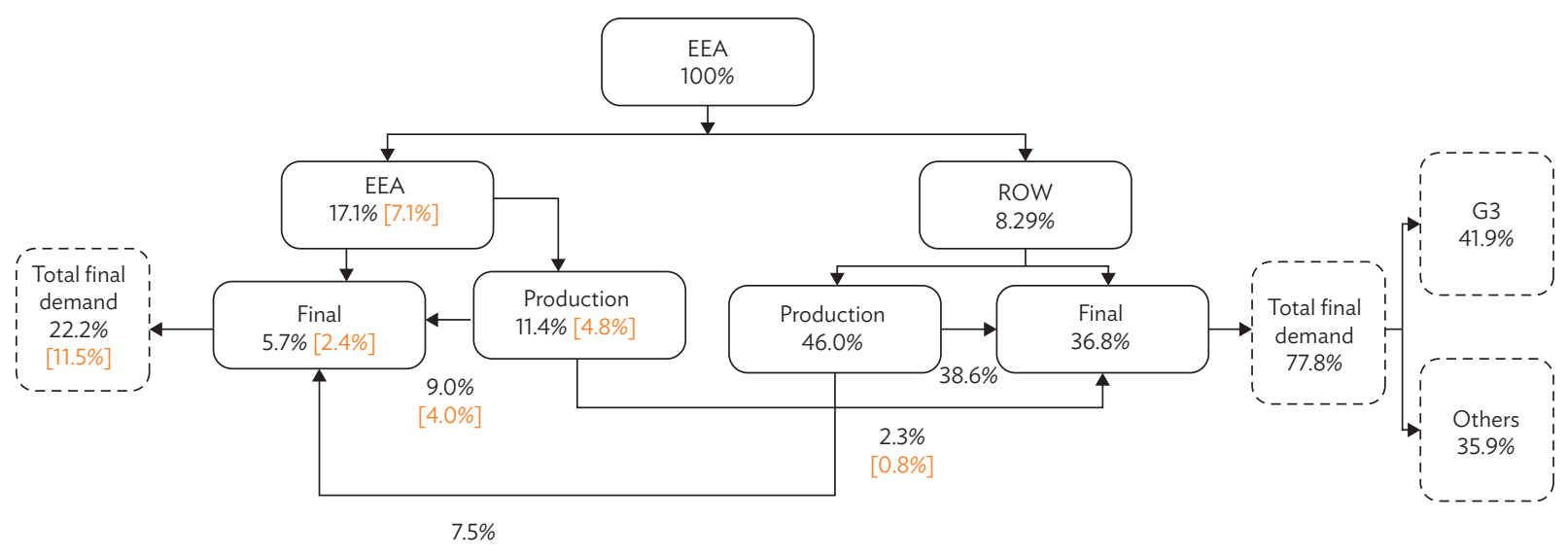

EEA $=$ emerging East Asia, $P R C=$ People's Republic of China, ROW $=$ Rest of the world, US = United States

Notes: G3 includes euro area, Japan, and the US. Value-added export decomposition is equal to domestic value added plus returned domestic value. Values for the PRC are in brackets.

Source: ADB calculations using data from ADB Multiregion Input-Output tables, and methodology from Wang, Zhi, Shang-Jin Wei, and Kunfu Zhu. 2014. "Quantifying International Production Sharing at the Bilateral and Sectoral Levels." NBER Working Paper No. 19677.

As intra-Asian trade is originated from demand outside the region, the growth of intraregional trade share in total Asian exports does not automatically lead to Asia's independence from an external demand shock. Contrarily, to the extent that intraregional trade is driven by intra-industry processing and assembly through vertically integrated production chains, Asian exports remain highly sensitive to a shock in major advanced economies. The global slowdown in the aftermath of the GFC originated from the US subprime mortgage sector and its ripple effects through the global financial system, and its impact on Asian exports were a vivid example of such sensitivity.

UNESCAP (2014) reports that strong growth in intrafirm and intra-industry trade through vertical supply networks of multinational companies has boosted Asian trade both intraregionally and interregionally. It suggests that regional production-sharing networks allowing multinational companies to take advantage of local specific conditions and low-cost labor might have been an underlying force behind the intraregional trade of intermediate goods destined for final consumption outside the region.

The PRC, as the region's main production base, has been at the center of this growing intraindustry and intraregional trade. In just 2 decades between 1985 and 2015, the PRC exports (imports) grew from $\$ 27$ billion ( $\$ 42$ billion) to $\$ 2,281$ billion ( $\$ 1,602$ billion). During this period of rapid growth, the pattern of PRC trade changed rather drastically. In the 1990s, the share of G3 markets steadily increased, reaching 50\% of total PRC exports by 2000 before declining gradually to around $35 \%$ in 2015. Meanwhile, the PRC imported more than a half of its total imports from Japan and EEA in the 1990s, although their collective share has fallen below 50\% in the past decade. However, from about 2000, the PRC has notably diversified its export and import partners, as the rest of the world takes up an increasing share of its total exports and imports (Figure 7). 


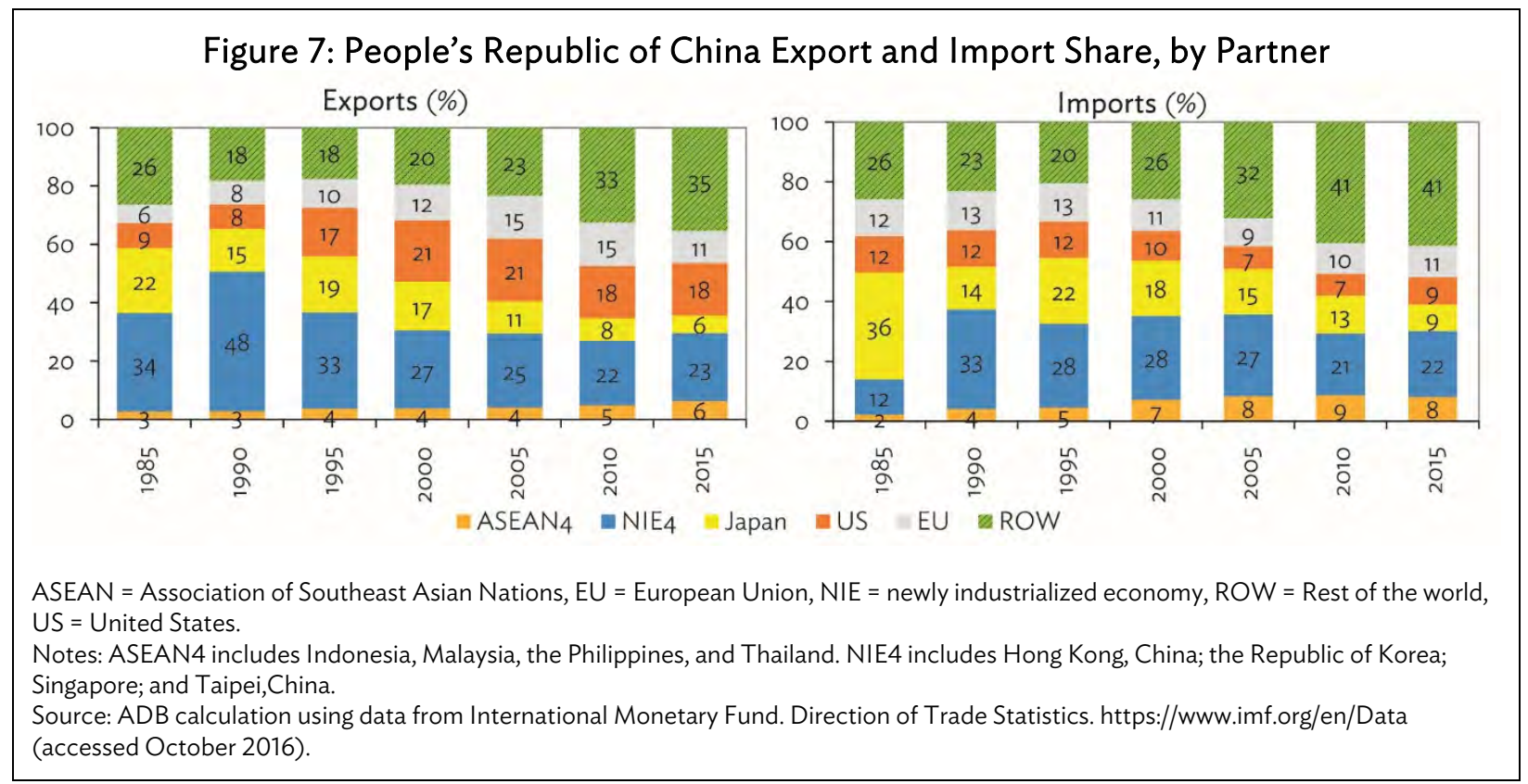

The basic pattern of the PRC trade in the 1990s can be characterized as the export of processed consumption goods to the US and the EU, while importing considerably large volumes of intermediate goods from regional economies. But since the mid-2000s, the PRC has emerged as a major importer of primary commodities while capital goods, rather than consumer goods, are leading its exports. This change in the trade pattern is well captured by the trend in the type of commodity exports and imports by the PRC (Figure 8). For example, about 70\% of the PRC's total imports consisted of primary and processed intermediate goods in the 1990s. By 2015, this rose to more than 75\%, with the share of primary intermediate goods expanding faster than that of processed intermediate goods, suggesting increasing PRC's self-production of intermediate goods. On the other hand, most of the PRC exports were consumption and processed intermediate goods in the 1990s and the share of capital goods in the PRC's total exports increased from 17\% to about 30\% from 2000 until 2015.

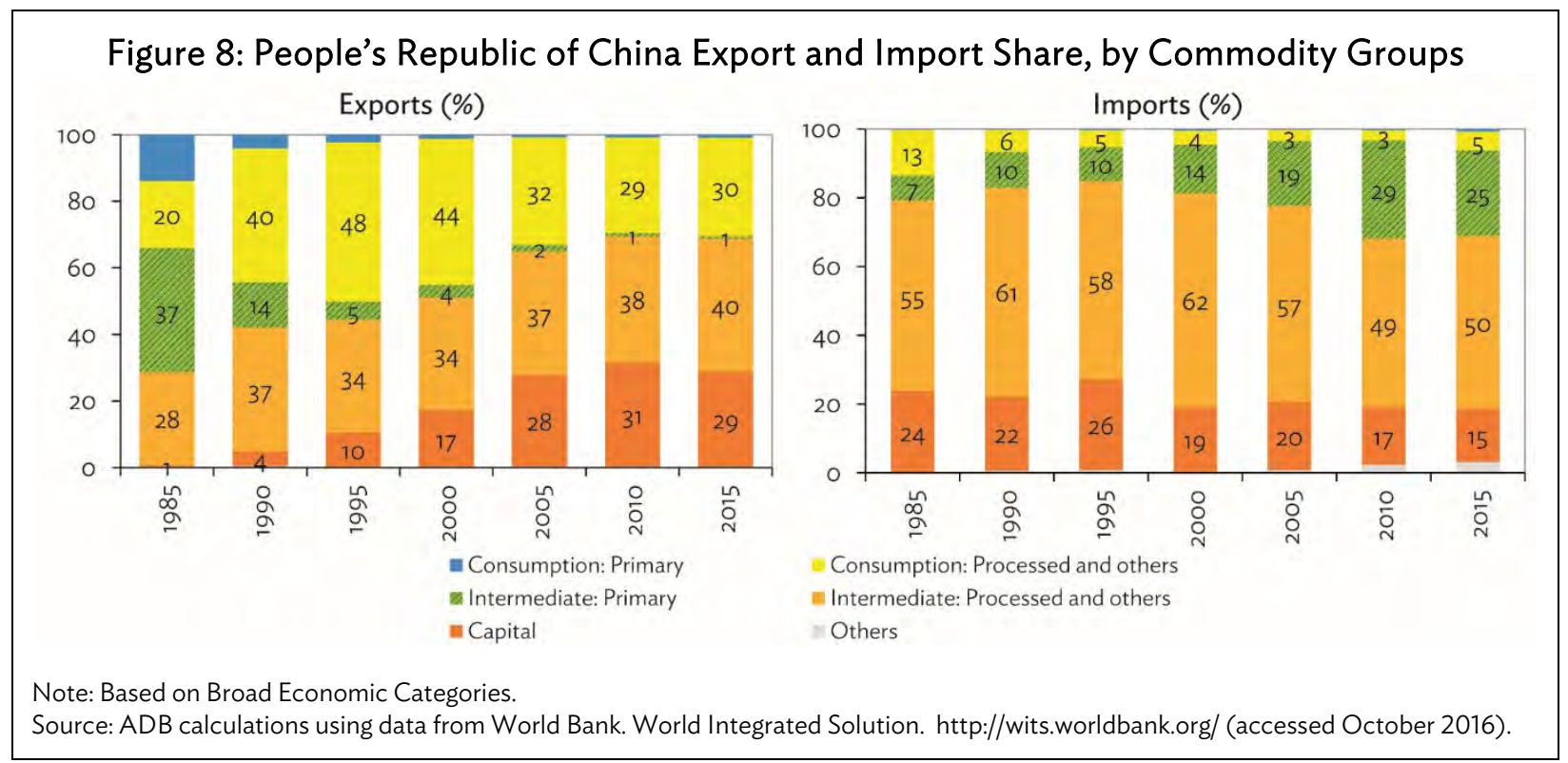




\section{The Trade-Foreign Direct Investment Nexus: Global Production Sharing in Asia}

FDI has played an important role in promoting intraregional and interregional trade of host countries (ADB 2007). Growth in inward FDI to EEA has been remarkable, rising from $\$ 22$ billion in 1990 to $\$ 426$ billion in 2015 . Excluding the PRC, the region attracted $\$ 290$ billion in 2015 , up from $\$ 18$ billion in 1990. The region has been the largest recipient region in the world, attracting almost a quarter of global FDI.

The pattern of inward FDI to Asia reveals firms' motivation of entry that is different from that into the rest of the world. Firms can enter the market (i) to avoid trade barriers and gain better access to local market by undertaking the same production activities in multiple countries (horizontal FDI), or (ii) to lower the production cost by relocating different stage of production in the country with the least cost (vertical FDI). Foreign affiliates in Asia established by FDI tend to be engaged more in trade and investment for the purpose of reexporting intermediate and/or final goods to the countries outside the host country (vertical and export-platform FDI) than those in other regions.

Rapid expansion of FDI to EEA has been closely associated with the establishment of regional production networks by multinational companies, especially with the PRC as the region's main assembly and production hub to create positive spillovers on the rest of the regional economies (Fukao, Ishido, and Ito 2003; Kawai and Urata 2004; Eichengreen and Tong 2005; and ADB 2006). Indeed, based on the number of foreign affiliates in Asia that both import and export, the PRC is the most popular host for vertical and export-platform FDI (Table 1) with various parent economies. By sector, inward FDI from trade-oriented firms is mostly concentrated in manufacturing, except in Hong Kong, China where it is mostly going to business services (Table 2).

\section{Table 1: Most Common Economy Pairs for Trade-Oriented FDI Firms}

\begin{tabular}{llcc}
\hline & & \multicolumn{2}{c}{ FDI Firms that Import and Export } \\
\cline { 3 - 4 } Destination & \multicolumn{1}{c}{ Origin } & Number & \% of Total \\
\hline 1. PRC & Japan & 2,260 & 81 \\
2. PRC & Hong Kong, China & 1,314 & 76 \\
3. PRC & United States & 646 & 74 \\
4. PRC & Germany & 625 & 76 \\
5. PRC & Taipei,China & 401 & 79 \\
6. PRC & Republic of Korea & 358 & 86 \\
7. PRC & Singapore & 337 & 71 \\
8. Viet Nam & Japan & 306 & 72 \\
9. Thailand & Japan & 258 & 64 \\
10. Indonesia & Japan & 214 & 53 \\
11. Taipei,China & Japan & 212 & 74 \\
12. PRC & France & 177 & 77 \\
13. Malaysia & Japan & 175 & 78 \\
14. Philippines & Japan & 171 & 69 \\
15. Singapore & Japan & 164 & 54 \\
\hline
\end{tabular}

$\mathrm{FDI}=$ foreign direct investment, $\mathrm{PRC}=$ People's Republic of China.

Source: ADB. 2016. "Special Theme: What Drives Foreign Direct Investment in Asia and the Pacific?" In Asian Economic Integration Report 2016. Manila. 
Table 2: Inward FDI from Trade-Oriented FDI Firms-EEA Economies, By Sector

\begin{tabular}{lccc}
\hline Host Economies & Mining & Manufacturing & Business Services \\
\hline PRC & 0.005 & 0.980 & 0.014 \\
\hline Indonesia & 0.005 & 0.796 & 0.200 \\
Malaysia & 0.020 & 0.955 & 0.022 \\
Thailand & 0.031 & 0.958 & 0.010 \\
Viet Nam & 0.005 & 0.989 & 0.006 \\
\hline Hong Kong, China & 0.008 & 0.311 & 0.674 \\
Republic of Korea & 0.035 & 0.930 & 0.030 \\
Singapore & 0.019 & 0.682 & 0.276 \\
Taipei,China & 0.027 & 0.918 & 0.055 \\
\hline India & 0.012 & 0.587 & 0.399 \\
Japan & 0.014 & 0.784 & 0.201 \\
Australia & 0.053 & 0.828 & 0.114 \\
\hline
\end{tabular}

$\mathrm{EEA}=$ emerging East Asia, $\mathrm{FDI}=$ foreign direct investment, $\mathrm{PRC}=$ People's Republic of China.

Notes: Each row shows the fraction of foreign affiliates that export and import in country $i$ in each sector.

Each row should sum up to 1.

Source: ADB. 2016. "Special Theme: What Drives Foreign Direct Investment in Asia and the Pacific?" In Asian Economic Integration Report 2016. Manila.

Table 3 points to an important issue regarding the headquarters of parent companies and the activity of their foreign affiliates operating in EEA. Foreign affiliates with an emerging East Asian parent company are much more likely engaged in international trade than the affiliates with non-East Asian parent companies, although their numbers are limited. The effect is coming from foreign affiliates of parent companies from high-income East Asian economies (the NIE4). But even foreign affiliates of middle-income Southeast Asian multinationals are also more engaged in international trade than the ones belonging to multinationals from outside Asia.

Table 3: Number of FDI Firms by Parent Economy

\begin{tabular}{lcc}
\hline $\begin{array}{l}\text { Parent Economy/ } \\
\text { Region }\end{array}$ & $\begin{array}{c}\text { Total Number } \\
\text { FDI Firms }\end{array}$ & $\begin{array}{c}\text { Proportion that } \\
\text { Imports and Exports (\%) }\end{array}$ \\
\hline Emerging East Asia & 47,057 & 36.2 \\
PRC & 31,298 & 31.6 \\
ASEAN3 & 2,788 & 30.4 \\
NIE4 & 12,971 & 48.4 \\
Rest of the world & 183,073 & 9.9 \\
India & 52,009 & 11.2 \\
Japan & 104,066 & 6.3 \\
US & 3,369 & 41.4 \\
EU & 6,128 & 48.4 \\
\hline
\end{tabular}

ASEAN = Association of Southeast Asian Nations, EU = European Union, FDI = foreign direct investment, NIE = newly industrialized economy, PRC = People's Republic of China, US = United States.

Notes: ASEAN3 includes Indonesia, Malaysia, and Thailand. Based on global ultimate headquarters. Source: ADB calculations using data from ADB. 2016. "Special Theme: What Drives Foreign Direct Investment in Asia and the Pacific?" In Asian Economic Integration Report 2016. Manila.

Strong trade and FDI linkages will likely be a channel of shock transmission. As the PRC has emerged as an important hub for intra-industry and intraregional trade and investment in Asia, economic interdependence between the PRC and the rest of Asia has likely increased. However, provided that the PRC imports a large share of the intermediate goods from the rest of Asia to serve final demand in the $G 3$, a slowdown in the $G 3$ economies could also have negative impact on the PRC exports, thus reducing PRC imports from the rest of Asia. At the same time, to the extent that FDI 
flows are related to intrafirm and intra-industry trade to serve external demand, FDI flows are likely to be responsive to the prospect of export growth. A sharp fall in exports and subsequently a reduction in FDI may hurt the PRC economy and then spill over to the rest of Asia.

\section{FINANCIAL INTEGRATION AND SPILLOVERS}

Financial integration, in theory, offers many benefits, such as better consumption smoothing through international risk sharing, more efficient allocation of capital for investment, and enhanced macroeconomic and financial discipline (Park and Lee 2011). However, in practice, tighter financial linkages also generate a higher risk of cross-border financial contagion, as illustrated by the episodes of financial crisis.

Assessing and monitoring the progress of financial market integration is important for understanding its impact on business cycle synchronization. Therefore, we empirically investigate the degree of financial integration among EEA equity and bond markets both in terms of quantity and prices.

\section{A. Empirical Analysis of Asia's International Assets Portfolio}

With greater capital account openness, the shares of international portfolio assets and liabilities held by Asian economies have increased. Figure 9 shows the trend of the cross-border portfolio asset holdings of AXC economies by region since 2001, based on the IMF Coordinated Portfolio Investment Survey data. ${ }^{5}$ The value of the region's foreign portfolio asset holdings surged from $\$ 331.9$ billion in 2001 (2.6\% of world total foreign portfolio assets) to $\$ 2.6$ trillion (5.6\%) in 2015 . When the value is scaled by GDP, the size of AXC's foreign asset holdings increased from $26.3 \%$ of GDP in 2001 to $67.7 \%$ in $2015 .{ }^{6}$

The data on asset holdings of a country can be also interpreted as liabilities by the counterpart country. For example, the Republic of Korea's holding of financial assets in Thailand can be interpreted as Thailand's liability to the Republic of Korea. Figure 10 illustrates EEA's financial liabilities by their geographic destinations since 2001. The US and the EU comprise the major share of EEA's financial liabilities, which makes the region vulnerable to changes in their financial conditions. For example, during the GFC, tightening credit conditions in the US and the EU prompted repatriation of their investment funds in EEA.

Hong Kong, China; the Republic of Korea; and Singapore are the three largest investors among EEA economies. Hong Kong, China held international portfolio assets of approximately $\$ 1.3$ trillion, or $2.7 \%$ of world total international portfolio assets in 2015 . Singapore held $\$ 962$ billion and the Republic of Korea held $\$ 236$ billion. On average for an individual economy, however, the EEA economies held foreign portfolio assets worth $\$ 359$ billion in 2015 , which is much lower than the $\$ 738$ billion average for an economy that is part of the EU.?

5 The Coordinated Portfolio Investment Survey is a voluntary data collection exercise, conducted under the auspices of the IMF, that collects an economy's data on its holdings of portfolio investment securities (data are separately requested for equity and investment fund shares, long-term debt instruments, and short-term debt instruments).

6 The PRC started reporting portfolio holdings only in $\mathrm{H} 1$ 2015. If the PRC data were included, the value of the EEA's foreign portfolio asset holdings for 2015 is $\$ 2.9$ trillion (6.2\% of world foreign portfolio assets). When the value is scaled by GDP, the size of EEA's foreign asset holdings is 19.4\% in 2015.

7 EU member economies included in the database are Austria, Belgium, Bulgaria, Cyprus, Czech Republic, Denmark, Estonia, Finland, France, Germany, Greece, Hungary, Ireland, Italy, Latvia, Lithuania, Luxembourg, Malta, the Netherlands, Poland, Portugal, Romania, Slovak Republic, Slovenia, Spain, Sweden and United Kingdom. Data for Croatia are not available. Data for Ireland are not included, since there is no data in 2015. 

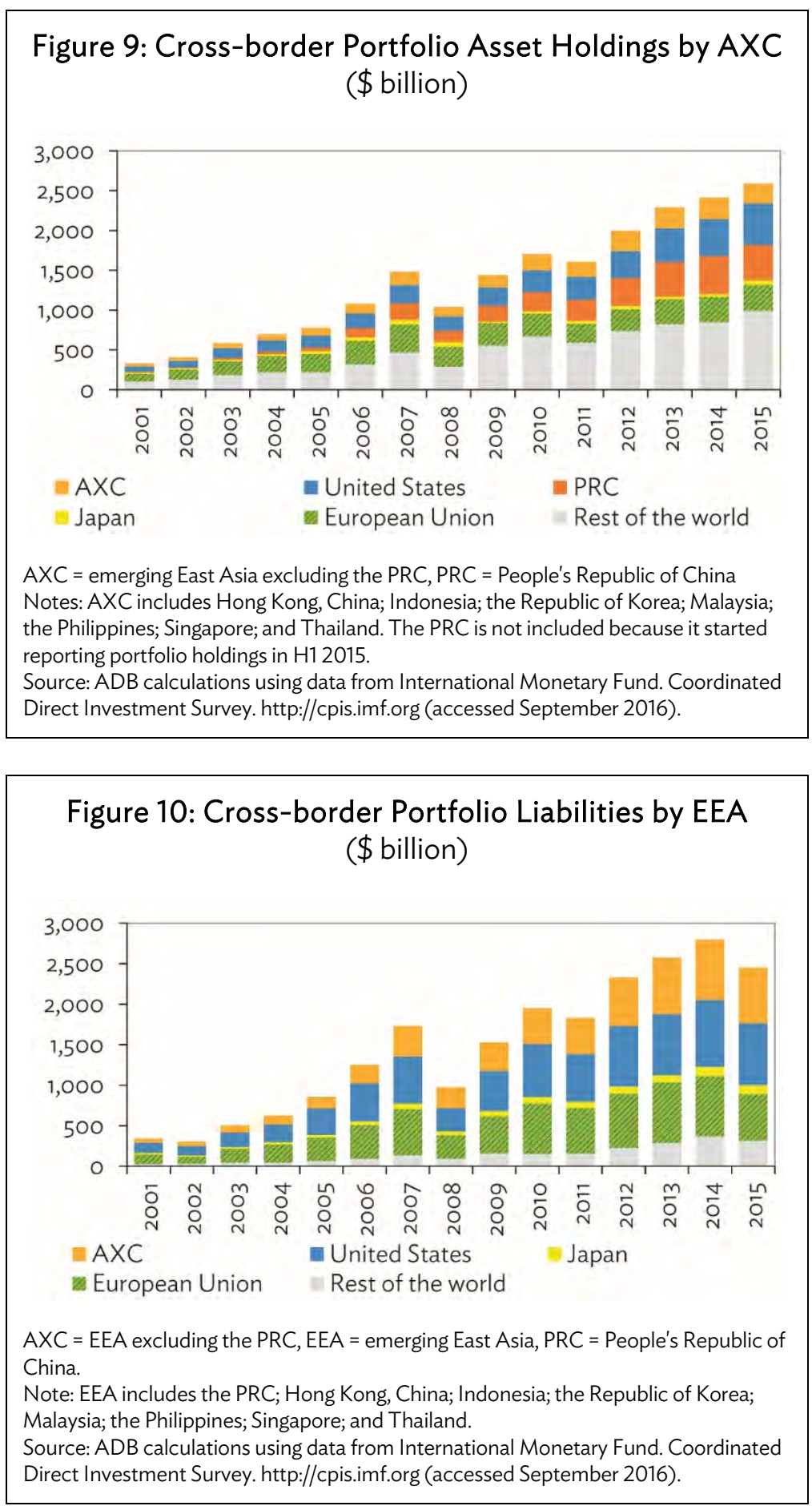

The region's foreign portfolio asset holdings have also become more geographically balanced since 2001. If EEA financial markets have become more regionally integrated, then a higher share of financial assets should be traded within the region and held by regional investors. The share of the EU and the US economies' as a percentage of EEA's total foreign assets has declined from $48 \%$ in 2001 to $34.8 \%$ in 2015 (32.8\% for AXC), while the share of the PRC and the rest of the world increased substantially from $34.8 \%$ to $51.8 \%$ (55.3\% for AXC). Second, EEA's foreign portfolio assets are 
increasingly being invested in the region. Regional portfolio asset holdings increased from $14.7 \%$ to $26.4 \%$, with a large share invested in the PRC. Excluding the PRC, regional asset holdings are rather low and steady (they declined from 11.7\% of EEA's total foreign asset holdings in 2001 to 11\% in 2015).

Japan holds very few EEA assets (3\% of its total foreign assets in 2015) and invests heavily in the US (39\% in 2015). Including Japan, Asian economies still hold a sizeable share of foreign assets in the form of US assets. However, only $14.1 \%$ of Asian foreign assets were held within the region in 2015, although the share is up from 5.5\% in 2001 (Figure 11).

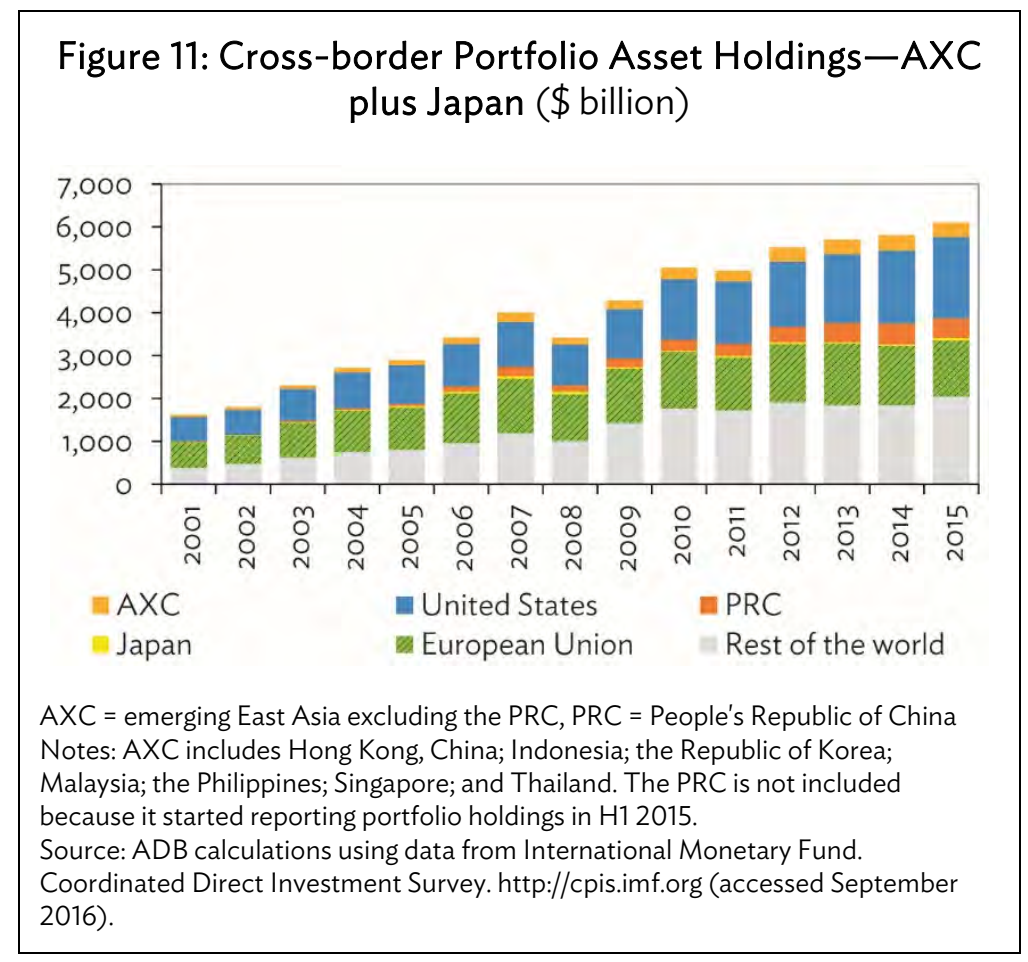

The sharp increase in EEA's international portfolio asset holdings nonetheless suggests a greater degree of financial openness and integration-both regionally and globally. However, the pace of financial integration in emerging Asia still lags behind that in Europe. The international portfolio asset holdings of an average EEA economy in 2015, 19.4\% of its GDP, are very low compared to an average EU country's 119\% of GDP. Moreover, the share of EEA's portfolio assets (both equities and debt securities) in the total international portfolio asset holdings of EEA in 2015 was much lower (26.1\%) than that of the EU asset holdings of EU economies (61.4\%).

If financial markets are fully integrated, assets with similar risk characteristics should be priced similarly (after adjusting for risks). In other words, greater financial integration should be accompanied by the closer comovement of financial asset prices.

The data used to measure the degree of comovement of financial asset returns comprise benchmark stock prices and bond return indexes, both sourced from Bloomberg. Correlations were computed between EEA and Japan, the eurozone, and the US and within EEA economies as well. For stock market returns, we calculate the weekly log differences of benchmark stock price indexes to get 
the continuously compounded weekly total returns from 1 January 1990 to 19 August $2016 .^{8}$ For bond returns, the total return indices of the JP Morgan Asia Diversified are used for EEA and Bloomberg Barclays indices are used for G3.9 Similar to stock market returns, weekly log differences were computed for bond return indexes from 31 December 2004 to 31 August 2016..$^{\circ}$ Using weekly-as opposed to daily - data can help avoid the potential problem of nonsynchronous data.

Table 4 presents the simple correlations in equity and debt markets, computed over the full sample period together with subsamples excluding crisis periods. Correlation coefficients of EEA stock markets' returns with advanced economies increased sharply following the AFC which continued after the GFC. Intraregional correlation among EEA also increased. These results illustrate the significant spillover effects of crisis on EEA markets and their increased financial integration with the advanced economies after 1998. Correlation of EEA bond market returns with EEA and G3 also rose after the GFC, although both intra and interregional correlations remain generally lower than those of the stock market.

\section{Table 4: Simple Correlations in Financial Asset Returns}

\begin{tabular}{ccccc}
\hline & Full sample & Pre-AFC & Pre-GFC & Post-GFC \\
\hline Equity Market Returns & & & & \\
EEA-EEA & 0.39 & 0.23 & 0.36 & 0.53 \\
AXC-PRC & 0.12 & 0.02 & 0.08 & 0.31 \\
EEA-JPN & 0.36 & 0.16 & 0.36 & 0.45 \\
EEA-Eurozone & 0.44 & 0.22 & 0.38 & 0.52 \\
EEA-US & 0.39 & 0.20 & 0.36 & 0.57 \\
Bond Market Returns & & & & \\
EEA-EEA & 0.23 & $\ldots$ & 0.10 & 0.28 \\
AXC-PRC & 0.13 & $\ldots$ & -0.01 & 0.17 \\
EEA-JPN & 0.17 & $\ldots$ & 0.15 & 0.20 \\
EEA-Eurozone & 0.21 & $\ldots$ & 0.23 & 0.24 \\
EEA-US & 0.25 & $\ldots$ & 0.17 & 0.29 \\
\hline
\end{tabular}

$\ldots=$ data not available, $\mathrm{AFC}=$ Asian financial crisis (1997/98), AXC = EEA excluding the PRC, EEA = emerging East Asia, GFC = global financial crisis (2008), JPN = Japan, PRC = People's Republic of China, US = United States.

Note: Due to data constraints, EEA countries for bond market returns only include Indonesia, Malaysia, the Philippines, Thailand, the Republic of Korea, Singapore, and the PRC.

Source: ADB calculations using data from Bloomberg LP (accessed October 2016).

To account for the time-varying dynamics ${ }^{11}$ of financial market correlations, especially during the episodes of financial crisis, we employ a simple model of Dynamic Conditional Correlation (DCC). ${ }^{12}$ The DCC model is a dynamic specification based on conditional correlations within the

8 For Singapore and the Eurozone, data series started from 31 August 1999 and 31 December 1996, respectively.

9 JP Morgan Asia Diversified is a suite of indices that tracks local currency government bonds issued by emerging and developed Asian countries (excluding Japan). https://www.jpmorgan.com/country/PH/en/detail/1320549416493

10 Data series for the Philippines started from 1 February 2008.

11 The descriptive statistics for the emerging East Asian economies indicate that the variances of the different series' returns neatly increased during the crisis. All series' returns are not normally distributed (Skewness $\neq 0$ and Kurtosis $\neq 3$ ).

12 The dynamic correlations are constructed as

$$
R_{t}=(1-\alpha-\beta) \bar{R}+\alpha\left(\varepsilon_{i, t-1} \varepsilon_{j, t-1}\right)+\beta R_{t-1}
$$

where $\alpha$ and $\beta$ are key scalar parameters to be estimated, and $R_{t}$ is the time-varying correlation matrix whose elements are defined as

$$
\rho_{i, j, t}=q_{i, j, t} / \sqrt{q_{i i, t} q_{j j, t}}
$$

where $\bar{R}$ is the unconditional expectation of $\varepsilon_{i} \varepsilon_{j} ; \rho_{i j, j}$ is the conditional correlation between the asset returns of countries $i$ and $j$ at time $t$, and $q_{i, j, t}$ is the off-diagonal elements of the variance-covariance matrix. 
generalized autoregressive conditional heteroskedasticity or multivariate autoregressive conditional heteroskedasticity models and is developed by Engle (2002), Engle and Sheppard (2001) and Tse and Tsui (2002). It is a recent method allowing simultaneously modeling of variances and conditional correlations of several series.

The estimation consists of two steps. First, the conditional variance of each variable was estimated using a univariate autoregressive conditional heteroskedasticity procedure. Second, the standardized regression residuals obtained in the first step were used to model those conditional correlations that vary through time. This analysis attempts to infer how the region's financial markets move in relation to financial fluctuations in these systemic countries.

Figure 12 shows that the relationship between EEA equity returns and the three major economies' equity returns strengthened post-AFC and continued pre-GFC. After GFC, the relationship slightly weakened but eventually recovered to pre-GFC levels. The results also show that conditional correlations among EEA economies strengthened. Meanwhile, Figure 13 illustrates that the conditional correlations of EEA bond returns are generally lower than equity returns' and have been relatively steady -although increased slightly in post-GFC.

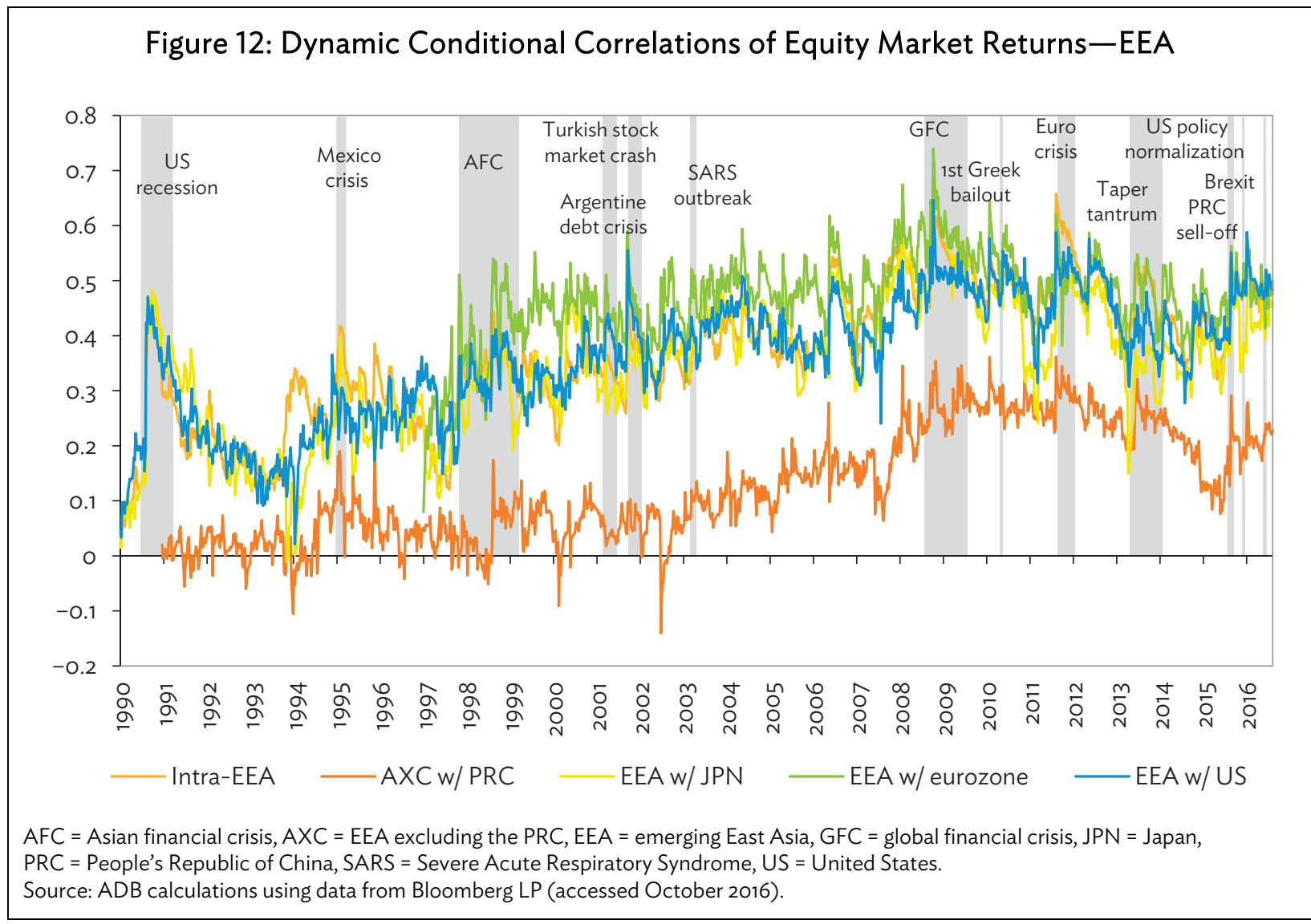




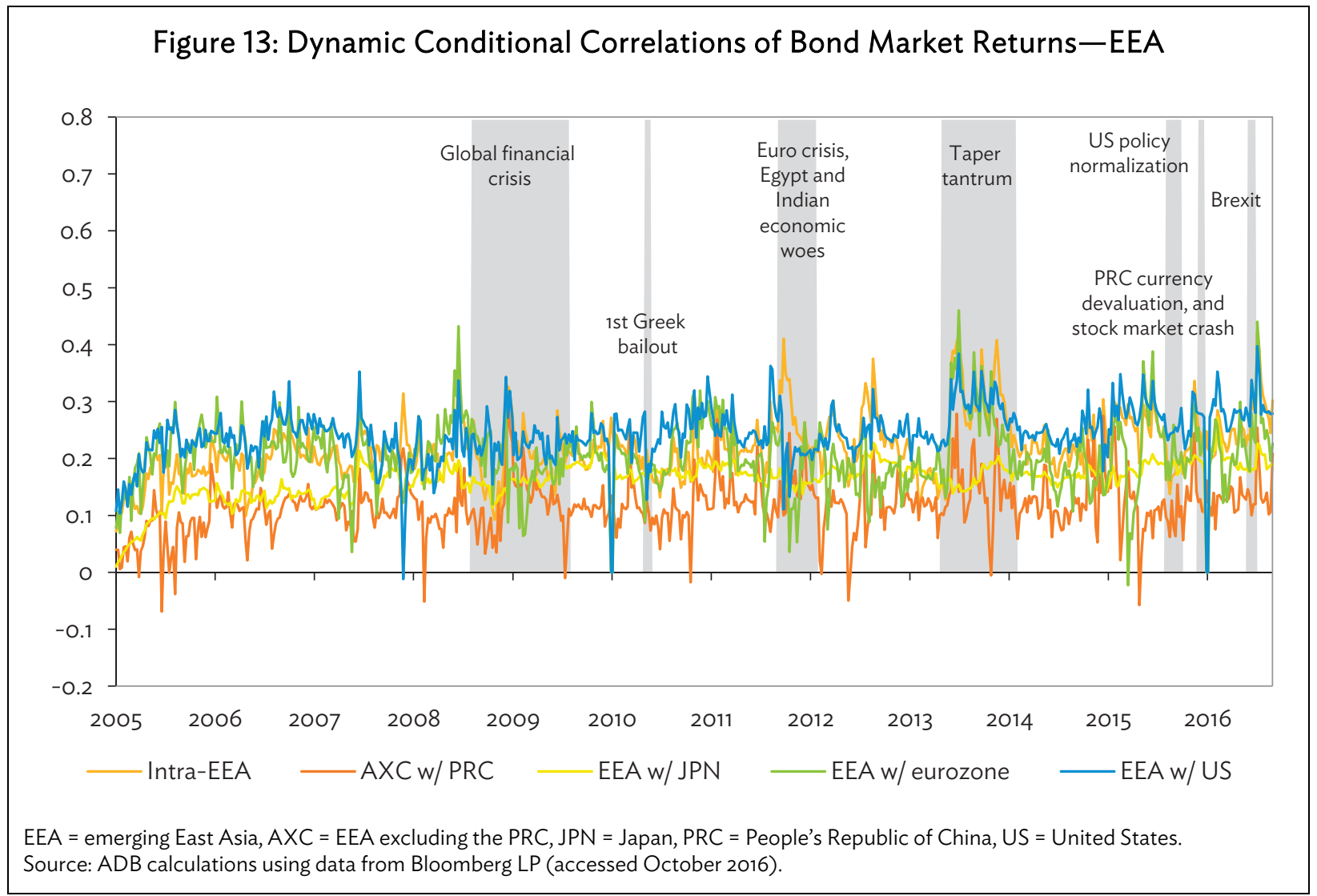

\section{B. Macroeconomic Interdependence: Vector Autoregression Model and Results}

A VAR model is employed to examine interregional and intraregional macroeconomic interdependence over three different sample periods, reflecting growing trade, investment and financial linkages. VAR models can identify the relevant structural shocks-such as those coming from the US output, global financial risk, as measured by the Chicago Board Options Exchange Volatility Index (VIX), global trade volume growth, the PRC output (as a proxy for regional shock), and individual AXC economies - and analyze the effects of each shock on an individual variable in a systematic way. equation:

Let's assume that an economy, $i(I=1,2, \ldots, 10)$, is described by the following structural form

$$
G(L) y_{t}^{i}=d^{i}+e_{t}^{i}
$$

where $G(L)$ is a matrix polynomial in the lag operator $L, y_{t}^{i}$ is an $m \times 1$ data vector, $d^{i}$ is an $m \times 1$ constant matrix, $m$ is the number of variables in the model, and $e_{t}^{i}$ denotes a vector of structural disturbances (Kim, Lee, and Park 2011).

By assuming that structural disturbances are mutually uncorrelated, $\operatorname{var}\left(e_{t}^{i}\right)$ can be denoted by $\Lambda$, which is a diagonal matrix where diagonal elements are the variances of structural disturbances. The individual fixed effect, $d^{i}$, is introduced to control for the country-specific factors that are not included 
in the model. We are interested in examining the time series relationship. Therefore, by including the individual fixed effect, we exclude the cross-sectional information in the estimation.

We estimated the following reduced form VAR with the individual fixed effects:

$$
y_{t}^{i}=c^{i}+B(L) y_{t-1}^{i}+u_{t}^{i}
$$

where $c^{i}$ is an $m \times 1$ constant matrix, $B(L)$ is a matrix polynomial in the lag operator $L$.

There are several ways of recovering the parameters in the structural form equation from the estimated parameters in the reduced form equation. The identification schemes under consideration impose recursive zero restrictions on contemporaneous structural parameters by applying Cholesky decomposition to the reduced form residuals, $\Lambda$, as in Sims (1980).

For each of the AXC economies, a five-variable VAR model (US, VIX, wtrade, PRC, AXC ) is constructed, where the contemporaneously exogenous variables are ordered first: US is the US output, VIX is from the Chicago Board Options Exchange Volatility Index, wtrade refers to global trade volume growth, PRC is PRC output, and $A X C_{i}$ is the output of each East Asian economy excluding the PRC. The first three variables are included to examine the relationship among external factors: US, VIX index, global trade growth, and the fourth variable, PRC is PRC output, which is a proxy for regional shock. The last variable is included to examine the effects of the local factors on the output of individual East Asian economies.

Some orderings of the variables can be regarded as a natural 1. The US output, the VIX index, global trade growth, and the PRC output are treated as contemporaneously exogenous to individual AXC country's output as individual AXC country's output is far smaller than the US and the PRC output. The US output (a proxy for the output of advanced economies), VIX, and world trade growth are all global factors, which should naturally be exogenous to AXC output. The PRC output is considered as a regional factor. The model assumes that the PRC output is unaffected by individual AXC economy output, but affected by the US output, global risk, and world trade growth. In contrast, the three global factors are assumed not affected by the PRC output contemporaneously.

We use quarterly data and estimate the model for the period before (Q1 1987-Q1 1997) and after the AFC (Q1 1999-Q2 2016). A constant term and four lags are assumed. As the measure of output, real GDP is used. Since we are interested in business cycle phenomena, we exclude the trend from data by applying a Hodrick-Prescott filter to give seasonally adjusted GDP at constant prices (Hodrick and Prescott 1981).

Figure 14 reports the aggregate impulse responses of the external shocks on individual AXC business cycles for both the pre- and post-AFC. The aggregate impulse responses are computed as the simple average of impulse responses across $A X C$ economies.

The results show that the effects of a US shock on individual AXC economies are quite substantial. Higher US output exerts a positive and persistent boost to AXC output; and the US impact appears to have strengthened after the AFC. In response to the US output shock prior to the crisis, AXC output increases by $0.09 \%$ on impact, peaks at $0.13 \%$ after the second quarter, then decreases and returns to the initial level after 3 quarters. After the AFC, the impact is much higher-peaking at $0.68 \%$, and more persistent as it dies down longer-after 6 quarters. 
Higher global risks - as measured by higher levels of the VIX index-exert negative effect on AXC output. The negative effect also appears to be larger and longer after the AFC than before it. It lasts for around 3 quarters before the crisis and 2 years after.

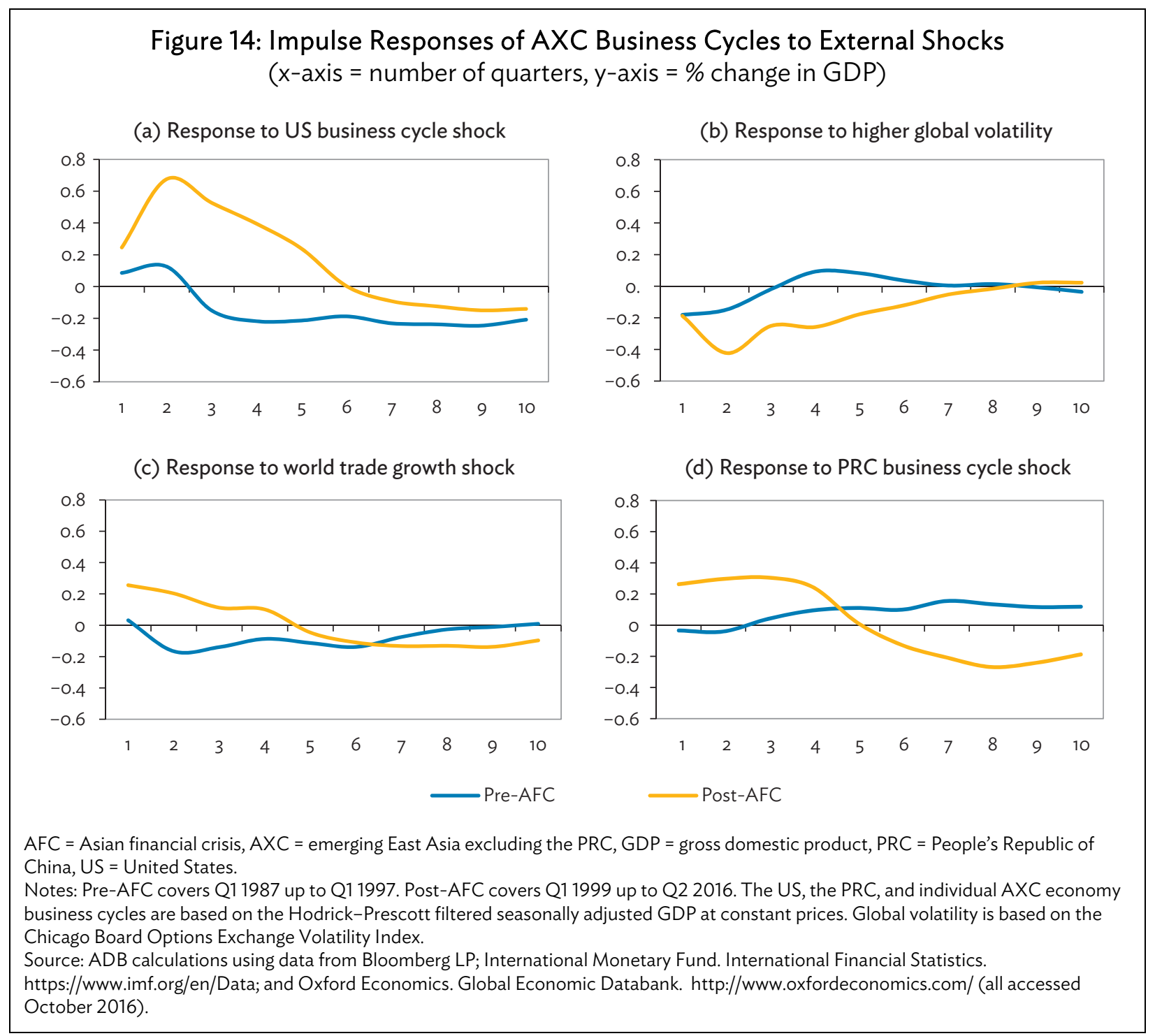

The impact of higher world trade growth on $A X C$ output is positive although not very big during the precrisis period. The effect is also short-lived as it dies down by the end of the first quarter. This may be due to the region's strong trade growth and resilience driven by strong growth in intraregional trade during this period. After the crisis, the positive effect is higher-at around $0.2 \%$ and dies down after a year. The pickup in the expansion of global/regional value chains together with the region's strong exports in the aftermath of the crisis might explain this positive effect.

Finally, a positive shock to the PRC output-after controlling for the impact of global factorshas different impact on AXC output before and after the AFC. Prior to the crisis, the effect is negative, although small, and lasts for around 3 quarters. After the crisis, the impact is positive and substantial, at around $0.3 \%$. It is also more persistent, lasting for more than a year. This shift from negative to positive effects of the PRC output shock may reflect that the shift in the PRC's role from a competitor to a 
collaborator and consumer for the region's producers/exporters. The PRC has become increasingly more integrated into the regional value chain while increasing imports from the region's trading partners in the past 2 decades.

Figure 15 shows the share of $A X C$ output variances (average share across 10 quarters) due to both external and domestic factors. It reveals that shocks to internal factors tend to explain most of the output variance in precrisis, although the impact has weakened postcrisis-from $57.6 \%$ to $40.8 \%$. Of the four external factors, the shares of the US output and the PRC output-as a proportion of output variance-increased the most after the crisis. The share of the US output increased from 12.2\% to $26.4 \%$ over the two periods, while that of the PRC output increased from $7.2 \%$ to $12.7 \%$. Among individual AXC economies, the impacts of a US output shock increased sharply for Hong Kong, China; Taipei,China; Singapore; and Thailand (see Appendix). The impacts of a PRC output shock are also large for Hong Kong, China; the Republic of Korea; Malaysia; and Taipei,China.

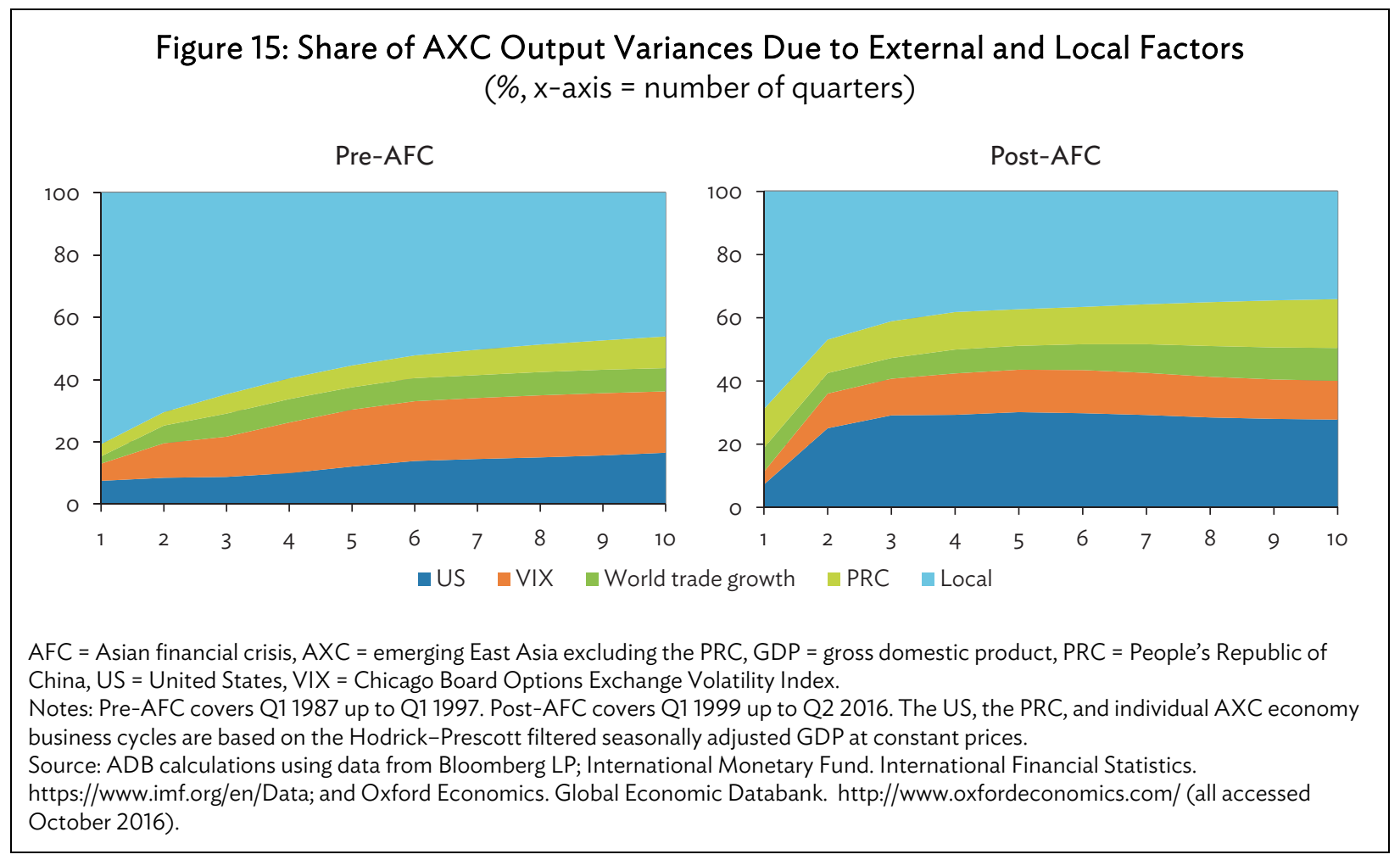

\section{CONCLUSION}

Nearly 2 decades ago, a devastating financial crisis swept across Southeast and East Asia. EEA stands strong with a remarkable record of high and sustained economic growth since then. Average annual growth in GDP reached 7.6\% over the past 2 decades. The strength of the region's exports, especially with the PRC at the center of tight regional production networks, has underpinned this performance.

Deepening trade and financial linkages within and beyond the region are strengthening expectation that EEA will gain greater macroeconomic independence from the US economy and become more resilient to global trade and financial shocks. However, findings of this study suggest no evidence to support Asia's decoupling from the world economy, both structurally and cyclically. 
The postcrisis economic recovery has been based on strong trade and financial openness, but deeper economic integration in EEA through increased trade and financial openness has led to not only greater economic integration within the region, but also to the region's integration with the global economy. While development of regional value chains through vertical specialization has led to increased productivity and opportunities to move up the value chain, expansion of Asia's trade and investment links has seen the region remain structurally linked to global final demand. EEA has become more, not less, integrated with the global economy and as a result, the impact of a global shock, whether related to trade or financial markets, will be greater. Further, deeper regional economic integration can help propagate a shock across economies of the region.

To the extent that Asian business cycles are sensitive to various external shocks, it is important that Asian countries maintain sound macroeconomic conditions and ensure coherent policy management. A stable macroeconomic environment of low inflation and prudent fiscal balances with modest levels of debt provides an important backdrop for sustaining high growth and allows room for policy makers to take macroeconomic stabilization measures whenever necessary.

Greater macroeconomic interdependence through tighter trade and financial linkages also requires greater cooperation in trade, finance, and exchange rate policies-both regionally and globally. As economic and financial shocks travel more rapidly from a country to its trading partners through increased trade and financial linkages, it is in the common interest of all Asian countries to maintain prudent national macroeconomic management, while strengthening regional policy cooperation. Synchronization of real growth and inflation in the region should also generate common interests to ensure close cooperation in macroeconomic and exchange rate policies.

Globalization, including the rapid relocation of production networks across borders, underscores the region's need for higher economic flexibility. Along with increasing openness to trade, globalization has allowed greater factor mobility. This implies that multinational companies can choose the most cost-efficient locations and relocate when the conditions of the current host economies deteriorate. The rise in intra-industry trade and trade integration has had a positive impact on economic growth by promoting efficiency and productivity growth. But easier relocation of the production base and greater factor mobility imply that Asian countries should ensure a high degree of flexibility in both product and factor markets to maintain their regional and global competitiveness.

To improve overall economic flexibility and competitiveness, further structural reforms should include the successful completion of corporate and finance sector restructuring by focusing on governance and legal infrastructure, creating an investment-friendly environment through minimizing regulatory barriers to business, encouraging private incentives toward more dynamic market economies, opening domestic markets to international competition, and creating conditions for equal policy treatment across all sectors. This will also help attract FDI.

The rapid integration of the PRC into the regional and global economies presents the rest of Asia with challenges and opportunities. The PRC's growing economy will play an increasingly vital role in promoting regional growth through expanding intraregional trade and financial flows. Although some Asian exporters may face nonnegligible adjustment costs as they find their comparative advantages over growing competition from the PRC economy, sound macroeconomic management, and comprehensive structural reform will ultimately contribute to higher economic efficiency and productivity, and therefore to greater economic welfare. 


\section{APPENDIX}

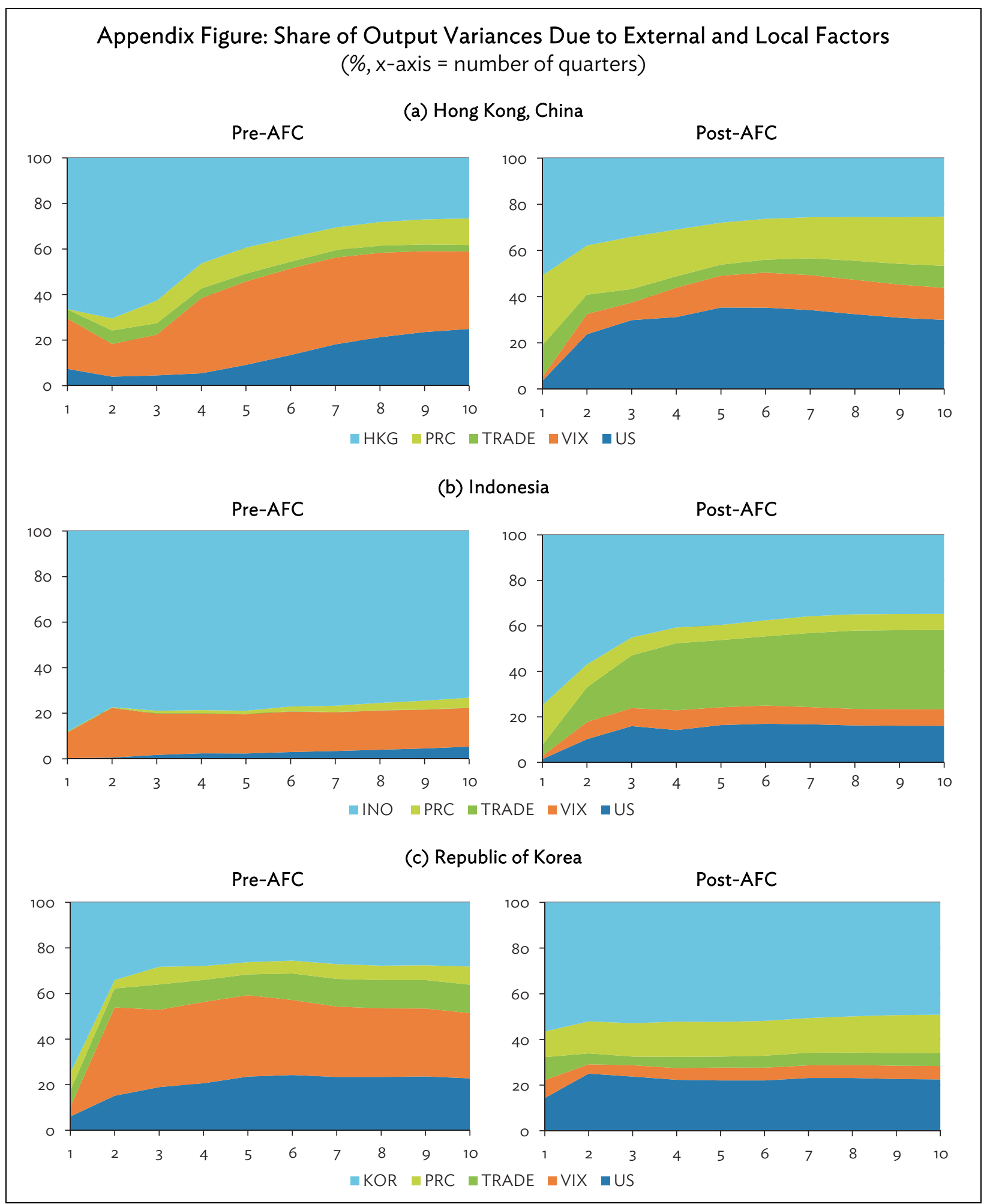


Appendix Figure continued

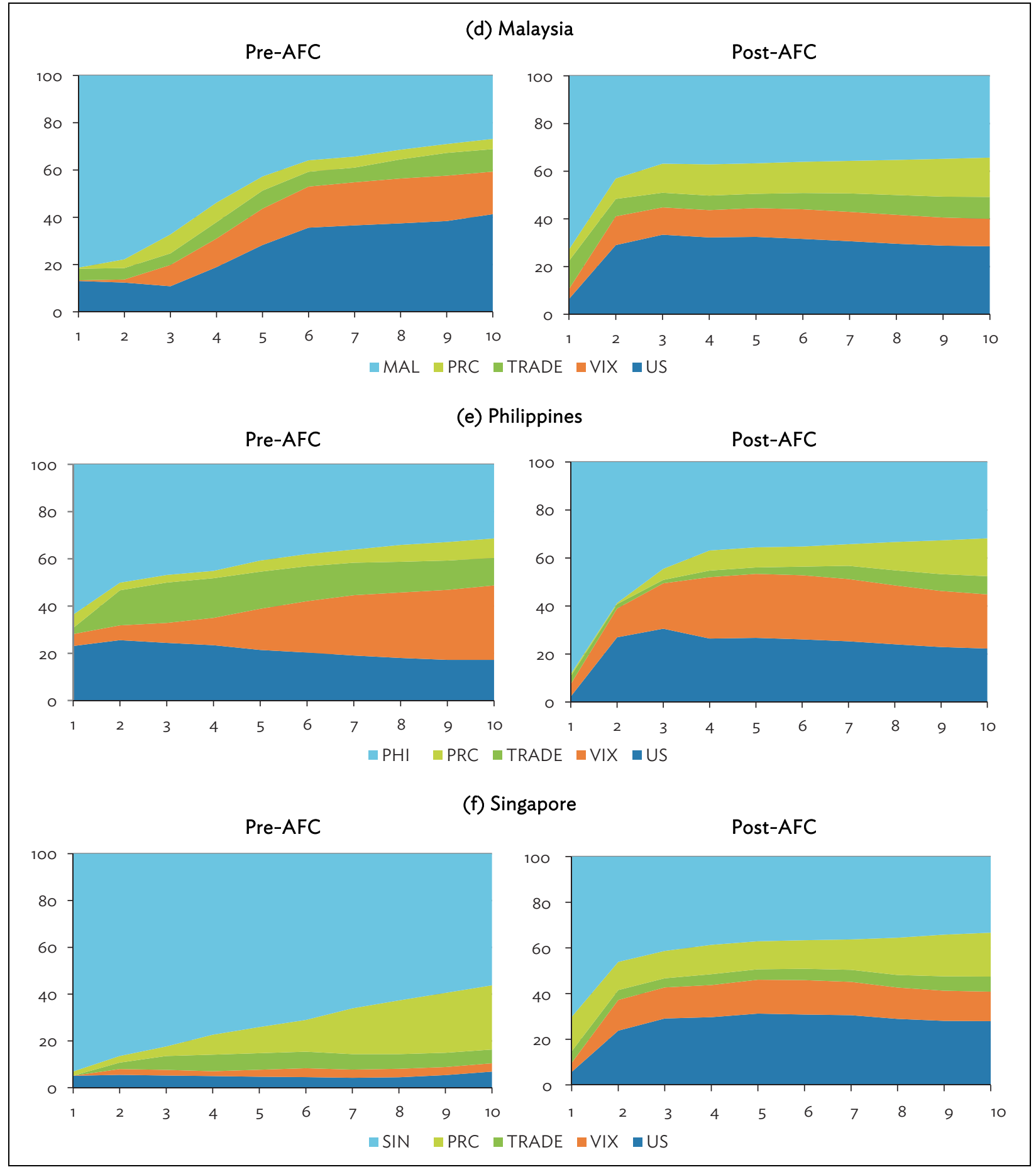

continued on next page 


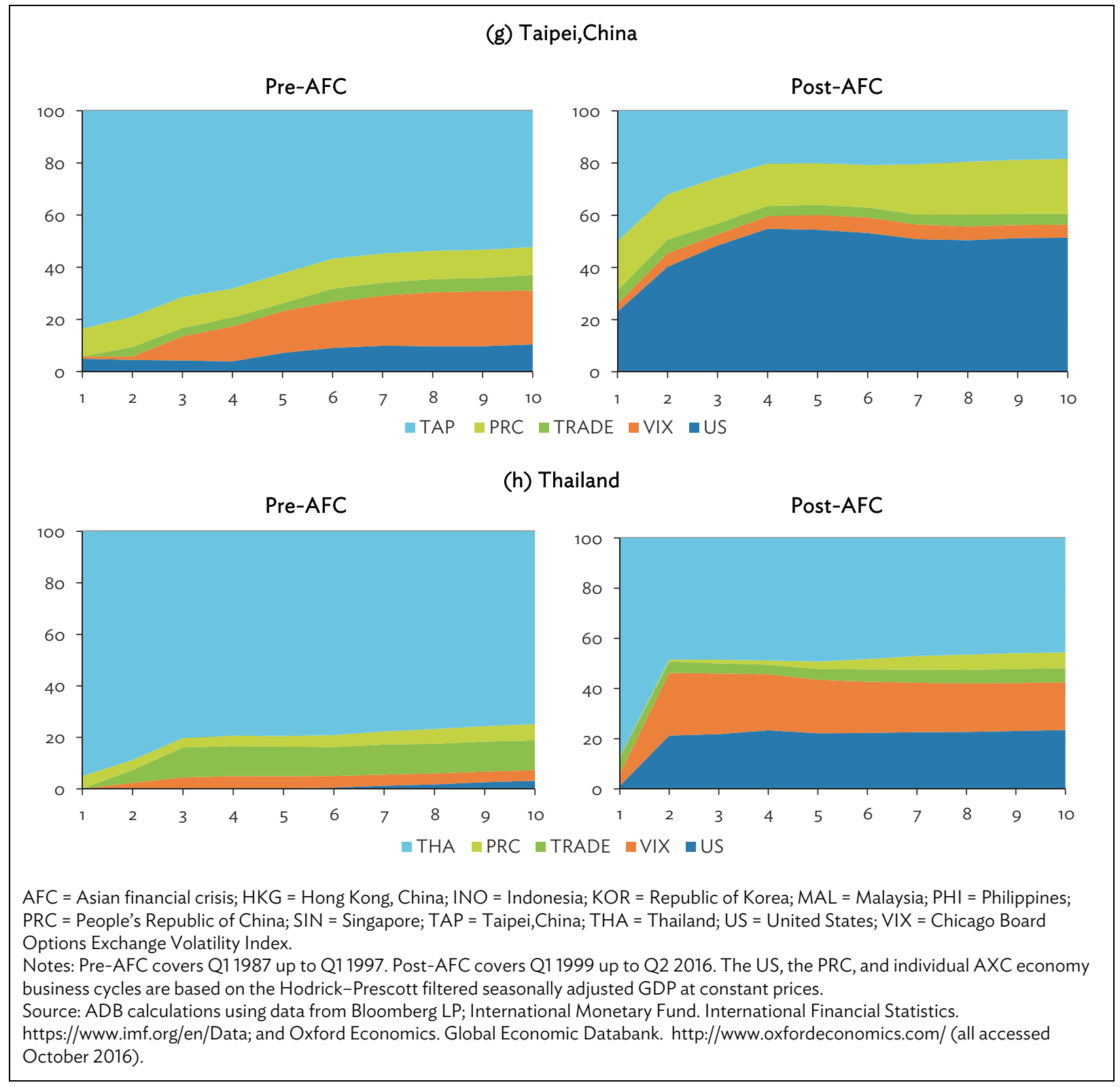




\section{REFERENCES*}

Abeysinghe, Tilak, and Kristin Forbes. 2005. "Trade Linkages and Output-Multiplier Effects: A Structural VAR Approach with a Focus on Asia." Review of International Economics 13 (2): 35675. doi:10.1111/j.1467-9396.2005.00508.x

Abiad, Abdul, Davide Furceri, Sebnem Kalemli-Ozcan, and Andrea Pescatori. 2013. "Dancing Together? Spillovers, Common Shocks, and the Role of Financial and Trade Linkages." In World Economic Outlook, October, 81-111. Washington: International Monetary Fund.

Asian Development Bank (ADB). Multiregion Input-Output Database.

_. 2006. "Developing Asia and the World." Asian Development Outlook 2006 Update. Hong Kong, China: Oxford University Press for the Asian Development Bank.

_2007. "Uncoupling Asia: Myth and Reality." In Asian Development Outlook 2007: Growth Amid Change. Hong Kong, China: ADB.

- 2016. "Special Theme: What Drives Foreign Direct Investment in Asia and the Pacific?" In Asian Economic Integration Report 2016. Manila.

Baxter, Marianne, and Michael Kouparitsas. 2005. "Determinants of Business Cycle Comovement: A Robust Analysis.” Journal of Monetary Economics 52 (1): 113-57. doi:10.1016/j.jmoneco.2004.08.002

Bloomberg Businessweek. 2008. “Are Asian Economies Decoupling from U.S.?” March 20.

Calvo, Sara, and Carmen M. Reinhart. 1996. "Capital Glows to Latin America: Is There Evidence of Contagion Effects?" In Private Capital Flows to Emerging Markets After the Mexican Crisis, edited by Guillermo A. Calvo, Morris Goldstein, and Eduard Hochreiter, 151-71. Washington, DC: Institute for International Economics.

Clark, Todd E., and Eric van Wincoop. 2001. "Borders and Business Cycles." Journal of International Economics 55 (1) : 59-85. doi:10.1016/S0022-1996(01)00095-2

Claessens, Stijn, Rudiger Dornbusch, and Yung Chul Park. 2001. "Contagion: Why Crises Spread and How This Can Be Stopped." In International Financial Contagion, edited by Stijn Claessens and Kristin J. Forbes, 19-41. New York: Springer.

Duval, Romain, Kevin Cheng, Kum Hwa Oh, Richa Saraf, and Dulani Seneviratne. 2014. "Trade Integration and Business Cycle Synchronization: A Reappraisal with Focus on Asia." IMF Working Paper 14 (52).

Eichengreen, Barry, and Hui Tong. 2005. "Is China's FDI Coming at the Expense of Other Countries?" NBER Working Paper No. 11335.

*ADB recognizes "China” as the People's Republic of China and "Korea” as the Republic of Korea. 
Engle, Robert. 2002. "Dynamic Conditional Correlation: A Simple Class of Multivariate Generalised Autoregressive Conditional Heteroskedasticity Models." Journal of Business and Economic Statistics 20 (3): 339-50. doi:10.1198/073500102288618487

Engle, Robert, and Kevin Sheppard. 2001. "Theoretical and Empirical Properties of Dynamic Conditional Correlation Multivariate GARCH.” NBER Working Paper No. 8554.

Frankel, Jeffrey A., and Andrew K. Rose. 1998. "The Endogeneity of the Optimum Currency Area Criteria.” The Economic Journal 108 (449): 1009-25. doi:10.1111/1468-0297.00327

Fukao, Kyoji, Hikari Ishido, and Keiko Ito. 2003. "Vertical Intra-Industry Trade and Foreign Direct Investment in East Asia." Journal of the Japanese and International Economies 17 (4): 468-506. doi:10.1016/j.jjie.2003.09.004

Heathcote, Jonathan, and Fabrizio Perri. 2004. "Financial Globalization and Real Regionalization." Journal of Economic Theory 119 (1): 207-43. doi:10.1016/j.jet.2003.06.003

Helbling, Thomas, Peter Berezin, Ayhan Kose, Michael Kumhof, Doug Laxton, and Nikola Spatafora. 2007. "Decoupling the Train? Spillovers and Cycle in the Global Economy." In World Economic Outlook, April, 121-60. Washington: International Monetary Fund.

Hodrick, Robert, and Edward Prescott. 1981. "Post-War US Business Cycles: An Empirical Investigation." Northwestern University, Center for Mathematical Studies in Economics and Management Science Discussion Paper 451.

Imbs, Jean. 2004. "Trade, Finance, Specialization, and Synchronization." The Review of Economics and Statistics 86 (3): 723-34. doi:10.1162/0034653041811707

_. 2006. "The Real Effects of Financial Integration." Journal of International Economics 68 (2): 296-324. doi:10.1016/j.jinteco.2005.05.003.

Inklaar, Robert, Richard Jong-A-Pin, and Jakob de Haan. 2008. "Trade and Business Cycle Synchronization in OECD Countries-A Re-examination.” European Economic Review 52 (4): 646-66. doi:10.1016/j.euroecorev.2007.05.003

International Monetary Fund. Direction of Trade Statistics. https://www.imf.org/en/Data (accessed October 2016).

_. International Financial Statistics. https://www.imf.org/en/Data (accessed October 2016).

—. Coordinated Direct Investment Survey. http://cpis.imf.org (accessed September 2016).

Kalemli-Ozcan, Sebnem, Bent E Sørensen, and Oved Yosha. 2003. "Risk Sharing and Industrial Specialization: Regional and International Evidence." American Economic Review 93 (3): 90318. doi:10.1257/000282803322157151

Kawai, Masahiro, and Shujiro Urata. 2004. "Trade and Foreign Direct Investment in East Asia." In Exchange Rate Regimes in East Asia, edited by Gordon de Brouwer and Masahiro Kawai, 15-102. London: RoutledgeCurzon. 
Kim, Soyoung, and Sunghyun H. Kim. 2013. "International Capital Flows, Boom-Bust Cycles, and Business Cycle Synchronization in the Asia Pacific Region." Contemporary Economic Policy 31 (1): 191-211. doi: 10.1111/j.1465-7287.2011.00285.x

Kim, Soyoung, Sunghyun H. Kim, and Yunjong Wang. 2007. "International Capital Flows and BoomBust Cycles in the Asia Pacific Region." Korea University Working Paper.

Kim, Soyoung, and Jong-Wha Lee. 2008. "Real and Financial Integration in East Asia." ADB Working Paper Series on Regional Economic Integration No. 17.

Kim, Soyoung, Jong-Wha Lee, and Cyn-Young Park. 2009. "Emerging Asia: Decoupling or Recoupling." ADB Working Paper Series on Regional Economic Integration No. 31.

2011. "Ties Binding Asia, Europe, and the USA." China and the World Economy 19 (1): 24-46. doi: 10.1111/j.1749-124X.2011.01225

Kose, M. Ayhan, Christopher Otrok, and Eswar S. Prasad. 2008. "Global Business Cycles: Convergence or Decoupling?” IMF Working Paper 8(143).

Kose, M. Ayhan, Eswar S. Prasad, and Marco E Terrones. 2003. "How Does Globalization Affect the Synchronization of Business Cycles?" American Economic Review 93 (2): 57-62. doi:10.1257/000282803321946804.

_. 2007. "How Does Financial Globalization Affect Risk Sharing? Patterns and Channels." IMF Working Paper 7(238).

Kose, M. Ayhan, and Kei-Mu Yi. 2002. "The Trade Comovement Problem in International Macroeconomics.” Federal Reserve Bank of New York Staff Report No. 155.

Kraay, Aart, and Jaume Ventura. 2007. "Comparative Advantage and the Cross-Section of Business Cycles." Journal of the European Economic Association 5 (6): 1300-33. doi:10.1162/jeea.2007.5.6.1300

Moneta, Fabio, and Rasmus Rüffer. 2006. "Business Cycle Synchronization in East Asia." European Central Bank Working Paper Series No. 671.

Oxford Economics. Global Economic Databank. http://www.oxfordeconomics.com/ (accessed October 2016).

Park, Cyn-Young, and Jong-Wha Lee. 2011. "Financial Integration in Emerging Asia: Challenges and Prospects.” Asian Economic Policy Review 5 (2): 176-98. doi:10.1111/j.1748-3131.2011.01193

Shin, Kwanho, and Yunjong Wang. 2004. "Trade Integration and Business Cycle Co-Movements: The Case of Korea with Other Asian Countries." Japan and the World Economy 16 (2): 213-30. doi:10.1016/s0922-1425(03)00028-8

Sims, Christopher A. 1980. "Macroeconomics and Reality." Econometrica 48 (1): 1-48. doi:10.2307/1912017 
The Economist. 2008. "The Decoupling Debate.” May 6.

Tse, Yiu Kuen, and Albert K. C. Tsui. 2002. "A Multivariate Generalized Autoregressive Conditional Heteroscedasticity Model with Time Varying Correlations." Journal of Business \& Economic Statistics 20 (3): 351-62. doi:10.1198/073500102288618496

United Nations Economic and Social Commission for Asia and the Pacific (UNESCAP). 2014. AsiaPacific Trade and Investment Report 2014: Recent Trends and Developments. Bangkok: United Nations.

United States Census Bureau. https://www.census.gov/ (accessed October 2016).

Wang, Zhi, Shang-Jin Wei, and Kunfu Zhu. 2014. "Quantifying International Production Sharing at the Bilateral and Sectoral Levels.” NBER Working Paper No. 19677.

World Bank. World Integrated Solution. http://wits.worldbank.org/ (accessed October 2016). 


\section{Decoupling Asia Revisited}

This paper investigates the channels of growth spillovers and estimates the degree of macroeconomic interdependence between emerging East Asia and G3 economies. First, it examines the progress of regional economic integration which has positively impacted the business cycle comovements both intraregionally and interregionally. Second, with the People's Republic of China playing a central role in the regional production network, its ongoing structural changes will likely influence Asia's trade patterns and economic integration. Finally, findings from vector autoregression model estimation suggest that the United States economy remains an important source of external demand shock for emerging East Asia, although the impact of the People's Republic of China has increased sharply.

\section{About the Asian Development Bank}

ADB's vision is an Asia and Pacific region free of poverty. Its mission is to help its developing member countries reduce poverty and improve the quality of life of their people. Despite the region's many successes, it remains home to a large share of the world's poor. ADB is committed to reducing poverty through inclusive economic growth, environmentally sustainable growth, and regional integration.

Based in Manila, ADB is owned by 67 members, including 48 from the region. Its main instruments for helping its developing member countries are policy dialogue, loans, equity investments, guarantees, grants, and technical assistance. 